\title{
Marka Evangelizminin Satın Alma Bağımlılığı, Satın Alma Niyeti ve Tavsiyede Bulunma Üzerindeki Etkisi: Taraftar Ürünleri Örneği \\ (The Effect of Brand Evangelism on Purchasing Addiction, Intention to Purchase and Recommendation: The Case of Fan Products)
}

\section{Bora GÖKTAŞ iD a İnci ERDOĞAN TARAKÇI iD $b$}

a Bayburt Üniversitesi Uygulamalı Bilimler Fakültesi, Yönetim Bilişim Sistemleri Bölümü, Bayburt, Türkiye. boragoktas@bayburt.edu.tr b Bilecik Şeyh Edebali Üniversitesi, Sağlık Bilimleri Fakültesi, Sağlık Yönetimi Bölümü, Bilecik, Türkiye. inci.erdgn@hotmail.com

\begin{tabular}{|c|c|}
\hline MAKALE BİLGİSI & ÖZET \\
\hline $\begin{array}{l}\text { Anahtar Kelimeler: } \\
\text { Marka evangelizmi } \\
\text { Pazarlama iletişimi } \\
\text { Tüketici davranışları }\end{array}$ & $\begin{array}{l}\text { Amaç - Marka evangelizmi ağızdan ağıza pazarlamanın daha gelişmiş halidir. Ağızdan ağıza } \\
\text { pazarlama; pazarlama iletişimi için bir iskeletse, marka evangelizmi bir ruhtur. Marka evangelizmi; } \\
\text { tüketicinin marka için, onun savunucusu, elçisi, avukatı gibi davranması, markaya büyük hayranlık } \\
\text { ya da büyük bir aşk beslemesidir. Türkiye'de marka evangelizmi konusunda yapılmış çalışmalar } \\
\text { oldukça sınırlıdır ve bundan dolayı da halen gelişime açıktır. Eldeki bu çalışma ile de marka } \\
\text { evangelizmi konusundaki alanyazınına katkı sunmak amaçlanmaktadır. }\end{array}$ \\
\hline $\begin{array}{l}\text { Gönderilme Tarihi } 2 \text { Ocak } \\
2020 \\
\text { Revizyon Tarihi } 7 \text { Mart } 2020\end{array}$ & $\begin{array}{l}\text { Yöntem - Çalışmada eFANgelizm ölçeği kullanılmış ve böylece marka evangelizminin satın alma } \\
\text { bağımlılığı, satın alma niyeti ve markayı tavsiye etme üzerindeki etkisi belirlenmeye çalışılmıştır. } \\
\text { Bu doğrultuda } 614 \text { katılımcı ile "kolayda örneklem yöntemi" ile bir anket yapılmış ve SPSS } 25 \text { paket } \\
\text { programında sınamaya tabi tutulmuştur. }\end{array}$ \\
\hline Naver I antul 11 iv & $\begin{array}{l}\text { Bulgular - Bulgular göstermektedir ki; marka evangelizminin satın alma bağımlılığı, satın alma } \\
\text { niyeti ve tavsiye etme üzerinde bir etkisi bulunmaktadır. Bundan dolayı pazarlama uzmanlarının } \\
\text { yapması gereken evangelist tüketiciler topluluğu meydana getirmektir. }\end{array}$ \\
\hline $\begin{array}{l}\text { Makale Kategorisi: } \\
\text { Araştırma Makalesi }\end{array}$ & $\begin{array}{l}\text { Tartışma - Pazarlama yöneticileri Evangelizm Pazarlama'yı pazarlama stratejilerinin bir parçası } \\
\text { olarak görmelidirler. İşletmenin yeni müşteriler kazanmasında evangelist tüketiciler kritik bir rol } \\
\text { oynayabilir ve markanın satışlarının artmasını sağlayabilir. Bunun nedeni, marka evangelistlerinin } \\
\text { herhangi bir çıkarı olmaksızın markanın elçiliğini yürütmeleri ve böylece olası müşterilerin ikna } \\
\text { olmasında etkili olabilmeleridir. }\end{array}$ \\
\hline
\end{tabular}

\begin{tabular}{ll}
\hline ARTICLE INFO & ABSTRACT \\
\hline Keywords: & $\begin{array}{l}\text { Purpose - Brand evangelism is a more advanced form of Word of mouth marketing. If word of } \\
\text { mouth marketing is a framework for marketing communication, brand evangelism is a spirit. In } \\
\text { brand evangelism }\end{array}$ \\
$\begin{array}{l}\text { Marketing communication } \\
\text { he/she is a great fan or a great lover of the brand. Studies conducted on the brand evangelism in } \\
\text { Tonsumer behavior }\end{array}$ & $\begin{array}{l}\text { Turkey is quite limited and is therefore still open to development. } \\
\text { Design/methodology/approach - With this study, it is aimed to contribute to the literature on brand } \\
\text { evangelism. For this purpose, eFANgelism scale was used in the study and thus the effect of brand } \\
\text { evangelism on purchasing addiction, intention to purchase and brand recommendation was tried to } \\
\text { be determined. In this respect, a questionnaire was conducted with } 614 \text { participants using }\end{array}$ \\
Received 2 January 2020 & $\begin{array}{l}\text { convenience sampling method" and tested in SPSS 25. } \\
\text { Accepted 11 March 2020 }\end{array}$ \\
$\begin{array}{l}\text { Findings - The findings show that; brand evangelism has an impact on on purchasing addiction, } \\
\text { intention to purchase and recommendation. Therefore, what marketing experts need to do is to } \\
\text { create a community of evangelist consumers. } \\
\text { Discussion - Marketing managers should see Evangelism Marketing as part of their marketing } \\
\text { Research Article }\end{array}$ & $\begin{array}{l}\text { strategy. Evangelist consumers can play a critical role in the business's acquisition of new customers } \\
\text { and increase the sales of the brand. Because brand evangelists run the embassy of the brand without } \\
\text { any interest, which can be effective in convincing potential customers. }\end{array}$
\end{tabular}




\section{Giriş}

Markaların hayatta kalmasında, rekabet avantajı yaratmasındaki en kritik noktalardan biri sadık müşteriler oluşturabilmektir. Çünkü pazarlamacılar tarafından; mevcut bir müşteriyi elde tutmanın, yeni bir müşteri elde etmekten çok daha ekonomik olduğu sık sık dile getirilmektedir. Bunun yanı sıra marka evangelizmi kavramı markalar için çok daha önemli, belki de bulunmaz bir nimettir. Çünkü evangelist tüketiciler; markanın sadece sadık müşterileri değil, aynı zamanda markanın propagandasını yapan ve hatta diğer müşterileri rakip markaları satın almaktan vazgeçiren birer markanın ücretsiz, gönüllü pazarlama temsilcileridirler. Bundan dolayı da marka evangelistleri pazarlama yöneticileri için sadık müşterilerden daha da kıymetli hale gelmektedir.

Müşteriler olumlu ağızdan ağıza pazarlama yaparak, tükettiği markanın temsilciliğini yapmaktadır. Bu temsilcilik ister istemez müşteriyi markanın savunucusu, avukatı konumuna getirmektedir. Bir markanın gönüllü savunucusu olan gerçek müşteriler, olası müşterilere yönelik gerçekleştirdikleri düşünce ve davranışları etkileme eylemleriyle onları gerçek müşteriye dönüştürmeye çalışmaktadırlar. Böylece evangelist müşteriler ağıdan ağıza pazarlamanın da ötesinde bir iş yaparak, güçlü bir ağızdan ağıza pazarlama faaliyeti gerçekleştirerek, markanın satın alınmasına katkıda bulunmaktadırlar.

Rashid vd., marka evangelizmi konusundaki çalışmaların hala yetersiz olduğunu ve bu alanda çalışmaların geliştirilmeye devam etmesi gerektiğine vurgu yapmaktadır (Rashid vd., 2017: 2866). Yapılan taramada Türkiye dışındaki ülkelerde marka evangelizmi hakkında yapılan çalışmaların gerçekten de hala çok az olduğu görülmektedir. Türkiye'de ise durum daha da geridedir ve yapılan çalışma sayısı bir elin parmağı kadardır. Bundan dolayı da marka evangelizmi konusunda hem Türkiye'de hem de dünyada hala doldurulması gereken bir boşluk bulunmaktadır. Eldeki çalışma ile marka evangelizmi konusundaki alanyazına bir katkı sunmak ve bahsi geçen boşluğun bir kısmını doldurabilmek amaçlanmaktadır. Çalışmada; marka evangelizminin satın alma bağımlılığı oluşturup oluşturmadığı, bunun yanı sıra satın alma kararına etki edip etmediği ve markanın tüketicilerinin evangelist pazarlamanın en kritik noktalarından biri olan tavsiye verme eylemlerini gerçekleştirme eğiliminde olup olmadıkları irdelenmekte ve bulgulara yer verilmektedir. Bunun için de araştırma konusu olarak spor kulüpleri seçilmiştir. Spor kulüplerinin taraftarları ne kadar evangelistlerdir ve bunu ne kadar uygulamaktadırlar? Soruları yanıtlanmaya çalışılmaktadır.

\section{Alanyazın Taraması}

\subsection{Evangelizm Pazarlama Kavramı}

Yunanca "evangelos" kelimesinden türeyen ve köken olarak "harikulade şeylerin habercisi, iyi haberler getiren" anlamını taşıyan "evangelist" kelimesi, 1990'1 yılların sonrasında internetin patlaması ile modaya uygun bir hale dönüşmüş ve "evangelizm" olarak adlandırılmaya başlanmıştır. Aynı zamanda evangelizm kelimesi "bir fikri teşvik etmek" olarak da kullanılmaktadır (Choudhury, 2019: 3). Milattan önce 300'lü yıllarda türemiş olan bu terim İncil'de "müjdeyi yayan" anlamında kullanılmakta ve "inananların, inanmayanları eğitmesi, heyecanlandırması ve inandırması" manasında kullanılmaktadır (Goldfayn, 2011: 8).

Evangelizm pazarlama kavramı ilk olarak Guy Kavasaki'nin 1996 yılındaki “Rakiplerinizi Çıldırtmanın Yolları" ve 2004 yılındaki "Girişimcinin El Kitabı" ile ortaya konmuştur (Saravanan ve Saraswathy, 2017: 2). Pazarlama yöneticileri de dâhil olmak üzere pek çok insan, Apple Computer'ın eski şefi olan Guy Kawasaki'nin evangelizm pazarlamasının babası olarak görmektedir. Kawasaki 1984 yılında Macintosh'un pazarlanmasından sorumlu kilit kişilerden biri olarak görülmektedir. Kawasaki, evangelizm pazarlamanın arkasındaki itici gücün bireylerin dünyayı daha iyi bir yer yapma istedikleri gerçeği olduğuna vurgu yapmaktadır. Evangelizm pazarlama, diğer insanlara hayallerini satmakla ilgilidir ve bundan dolayı da insanlar evangelistlerin söylediklerine inanmaktadırlar (Singh, 2015: 8). Evangelizm pazarlaması, markaya güçlü bir şekilde inanan müşterilerin olası müşterileri markayı satın almaya, kullanmaya ikna etmesi biçimde gelişen ileri düzey bir pazarlama uygulamasıdır. Marka evangelistleri, markayla ilgili daha önce olumlu bir deneyime sahip olduklarından dolayı markaya karşı olumlu duygular beslemektedirler ve markayla ilgili bu fikirlerini de yaymaktadırlar. Marka evangelistleri, fikirlerini gönüllü olarak yaydıkları, maksatları markadan karşılı̆̆ında bir çıkar elde etmek yerine, fayda yaratmak olduğundan dolayı olası müşteriler tarafından daha güvenilir olarak algılanmaktadırlar (Saravanan ve Saraswathy, 2017: 2). 


\section{B. Göktaş - İ. Erdoğan Tarakçı 12/1 (2020) 126-145}

Evangelizm pazarlamanın ortaya çıkmasında sadık müşterilerin büyük bir katkısı bulunmaktadır. Bir başka deyişle evangelizm pazarlama için sadık tüketicilerde büyük bir potansiyel vardır. Dolayısıyla sadık müşterilerin elde edilmesi marka savunucularının elde edilmesi demektir ve bu da güçlü ve kazançlı bir pazarlama stratejisidir. İyi uygulanmış marka evangelizmi programları, piyasada zaten var olan enerjiyi ve iyi niyeti daha da arttırmaktadır. Bu programlar; bir markanın yaptı̆̆ı yatırımlardan yararlanması için harika bir araçtır (Rusticus, 2006: 57). Marka tutkunları, marka topluluğu üyeleri, tüketici kabileleri, marka kültü üyeleri ve evangelist müşteriler; ücretsiz, denetleme gereği duyulmaksızın, markalar hakkında çevrimiçi ve çevrimdışı ortamlarda yorumlar yaparak marka için pazarlama faaliyetlerinde bulunmaktadırlar. Tüketiciler marka için evangelist olduğunda, o marka mümkün olan en iyi müşteriye sahip olmaktadır. Evangelist müşteriler; tutkulu, sadık ve markayı tavsiye etmekten heyecan duymaktadırlar. Onlar (zor zamanlar için özellikle) markayı savunan birer pazarlama iletişimcisidirler. Bundan dolayı da markalar için evangelizm pazarlama dikkate alınması, üzerinde durulması gereken bir kavramdır (Singh, 2015: 5).

Evangelizm pazarlaması, belirli bir mala veya hizmete çok güçlü inanan müşterilerin, başkalarını satın almaya ve kullanmaya serbestçe ikna etmeye çalıştıkları gelişmiş bir ağızdan ağıza pazarlama biçimidir. Burada müşteriler işletme adına aktif olarak sözcülük yapmakta, markayı yaymakta, markayı gönüllü olarak savunmaktadırlar (https://tr.scribd.com/document/28989043/Evangelism-Marketing). Sosyal ağların ortaya çıkmasıyla evangelizm pazarlaması, kuruluşların etkilerini müşterilerinin sosyal ağları yoluyla yaymak için kullandığı ana faktör haline gelmiştir. Bir markanın müşterisinin, marka ile ilgili görüşlerini sosyal ağlar aracılığıyla yayması markaya itibar kazandırmaktadır (Saravanan ve Saraswathy, 2017: 2).

Bir markanın kullanımından mutlu olan müşteriler, marka hakkında olumlu ağızdan ağıza pazarlama yapmakta, markayla ilgili diğer kişilere sürekli haberler vermekte, markanın yayılmasını, satın alınmasını sağlamaktadırlar. Bu da mutlu müşterilerin zamanla evangelist tüketicilere dönüştügünün göstergesidir. Kısacası marka mutluluğunun marka evangelizmi yaratılması üzerinde etkisi bulunmaktadır. Ayrıca evangelist ve mutlu tüketicilerin markayı yaptı̆̆ı hatalar karşısında affetme eğilimleri de yüksektir. Bir başka anlatımla marka evangelizmi ve marka mutluluğu, tüketicileri markanın yaptığı bir hata karşısında affetmeye teşvik etme gücüne sahip bulunmaktadır. Bu duygu pazarlamacıların mevcut tüketicileri ile ilişkileri sürdürmelerini, geliştirmelerini ve yeni tüketiciler kazanmalarını sağlamaktadır (Schnebelen ve Bruhn, 2018: 114).

\subsection{Marka Evangelizmi Kavramı}

Marka evangelisti: marka misyoneri, marka tutkunu, marka düşkünü, marka aşığı, marka avukatı, marka savunucusu, marka sözcüsü, marka elçisi, marka dostu, marka bağnazı, marka hayranı, marka fanatiği gibi anlamlarda da kullanılmaktadır (Matzler vd. 2009: 239; Doss, 2013: 2; Singh, 2015: 5; Choudhury, 2019: 2). Marka evangelizmi ile markayla ilgili deneyimlerini heyecanlı bir şekilde çevredeki diğer kişilerle tartışıp, onları kullanmaya teşvik etmek anlatılmaktadır. Marka evangelizmi coşkulu ve sosyal bir faaliyettir. Bu yöntemi yapan müşteriler; rakip markaları önemsizleştirmekte, kendi kullandıkları markayı diğer tüketicilerinde kullanması için ikna etmeye yönelik çabalar gerçekleştirmekte, onlara tavsiyelerde bulunmaktadırlar. Bu yönüyle de evangelist tüketiciler pazarlamacıların en dikkatini çeken müşterilerdir (Choudhury, 2019: 3).

Psikolojik olarak; bir markaya olan ilginin artması bir süre sonra tüketicileri evangelist bir biçime dönüştürebilmekte ve bunun sonucu olarak da ortaya marka toplulukları çıkabilmektedir. Marka evangelistleri; diğer tüketicileri kendi kullandıkları markanın safına çekebilmek için hararetli bir biçimde çaba sarf eden birer marka savunucularıdırlar (Swimberghea vd., 2018: 172). Tüketicilerin marka adına diğer insanlara taahhütlerde bulunması kolaylıkla oluşturulacak bir durum değildir. Bundan dolayı da markayla ilgili taahhütlerde bulunan tüketicilerin, öncelikle marka topluluklarının sonrasında da marka evangelistlerinin meydana gelmesi, diğer tüketicilerin davranışlarını etkilemekte kritik bir belirleyicidir (Shaari ve Ahmad, 2016: 78). Marka evangelistleri, bir markayı seven, o marka hakkında başkalarıyla da konuşmayı çok seven ve başkalarının da o markayı kullandığını bilmekten gurur duyun bir tüketici grubudur. Bundan dolayı da pazarlamacıların çabaları marka evangelizmini geliştirme üzerine olmalıdır. Müşterinin katılımını ve etkinliğini elde etmek için atılan adımlar aracılı̆̆ıyla egemen bir ilişki kurmaya odaklanmalıdır (Raj vd., 2013: 56). 


\section{B. Göktaş - İ. Erdoğan Tarakçı 12/1 (2020) 126-145}

Marka evangelistlerinin değerlendirmeleri sadece birkaç marka ile sınırlıdır. Bu tür tüketicilere, başkalarını etkileme yeteneklerinden dolayı pazarlamacılar özel bir ilgi duymaktadır. Markanın yeniden satın alınma olasılığı olarak tanımlanan marka sadakati, marka evangelizminin mantıklı bir bileşenidir. Markaya karşı genel bir pozitiflik ya da negatiflik duygularının marka evangelizmini güçlendirmesi veya zayıflatması durumu bulunmaktadır. Böylece tüketicilerin gelgitle mücadele etmekten çok gelgitlerini pekiştirmeleri olası bir durumdur (Cestare ve Lala, 2015: 2). Marka evangelistleri markanın karakterini ve özelliklerini ileten kişilerdir. Bu iletiler geleneksel pazarlama ile de iletişim kurabilecek marka mesajlarıdır. Marka evangelistleri verdikleri mesajlarla ailelerine, arkadaşlarına, meslektaşlarına ve topluluklarına benzersiz bir kişisel öneri sunmaktadırlar (Smilansky, 2009: 5). Marka evangelistliği tüketicilerin markayla ilk karşılaşmasından başlayan deneyimlerin sonucu olarak varılan bir yolculuktur. Anlamlı deneyimler marka evangelistliği yaratabilmektedir. Tecrübe ve evangelizm sıkıca iç içe geçmiş kavramlardır (Arkonsuo vd., 2014: 6).

Apple gibi büyük şirketlerin sadık tüketicileri vardır, bu Apple sadıkları, akıllı telefon pazarında en çok tanınan ürün evangelistlerinden bazıları, ürünlerle ilgili deneyimlerini çok heyecan verici bir şekilde iletmektedirler. 1984'te Marka Evangelizminin öncüsü olan Apple, pazarlama mesajların diğer potansiyel müşterilere iletmek için gerçek müşterilerine güvenmektedir (Anggarini, 2018: 64). Apple, kendisi hakkındaki farkındalığını yaymak ve talebin artmasını sağlamak için başlı başına evangelist çalışanlar kullanmıştır ve bu konuda da başarılı olmuştur. Bu başarılı evangelistler, tüketiciler arasında marka hakkında bilgiler yaymış ve diğer insanları da ürünün değeri konusunda ikna etmişlerdir (Pride ve Ferrell, 2016: 55).

Olumlu bir ağızdan ağıza pazarlamanın daha ileri, daha güçlü, evrimleşmiş bir seviyesi marka evangelizmi olarak tanımlanabilmektedir. Markanın adına bedel almaksızın konuşan bir sözcü, her zaman bir haberci olarak adlandırılmakta, onun eylemini başkalarının markayı kullanmalarını teşvik etmek için bir vaaz anlamına bile gelmektedir (Doss, 2013: 2). "Ağızdan ağıza pazarlama bir iskeletse, tüketici evangelizmi bir ruhtur" (Conley ve Fishman, 2006: 174). Marka evangelizmi; olumlu ağızdan ağıza pazarlama ve marka sadakatinin ötesinde, kişinin kendisini markaya adamasıdır (Matzler vd., 2009: 239).

Marka evangelizminin avantaj ve dezavantajları şunlardır (Saravanan ve Saraswathy, 2017: 3);

Avantajları

$\checkmark$ Diğer pazarlama kampanyası çabalarına kıyasla düşük maliyetli reklamcılık,

$\checkmark$ Araştırmalar marka evangelistlerinin, marka evangelisti olmayan bir müşteriden $\% 50$ daha fazla para (bireysel olarak) harcadığını göstermiştir,

$\checkmark$ Marka evangelistleri, markayı veya ürünleri iyileştirmenin ve geri bildirim sağlamanın yollarını aktif olarak ararlar,

$\checkmark$ Tarafsiz geri bildirim sistemi,

$\checkmark$ Bağlı müşteriler,

$\checkmark$ Uzun vadeli pazarlama stratejisi,

$\checkmark$ Artan şerefiye,

$\checkmark$ Giderlerin yönetimi,

$\checkmark$ Yatırımların geri dönüşü kısalığı gibi avantajları bulunmaktadır

Dezavantajları

$\checkmark$ Kötü ürün tasarımı, kötü müşteri hizmeti, ürün deneyimi olumsuz bir marka oluşmasına ve olumsuz bir marka birliği oluşmasına yol açabilir,

$\checkmark$ Pazarlama mesajı ve dağıtım yöntemi üzerinde kontrol eksikliği vardır.

Marka evangelizmi, memnun müşterileri üç aşamaya ayıran marka evangelizmi piramidi ile daha iyi anlaşılabilmektedir. İlk aşamada "markayı benimseyenler" grubu bulunmaktadır. Bu grup bir markayla ilgili en büyük sınıftır. Bunlar markayla ilgili tatmin edici bir deneyim yaşadığı için, normal kullanıcılara yön veren bir müşteri kesimidir. Piramidin ikinci aşaması olan "marka hayranları", markadan son derece memnun kalan mevcut müş̧erileridir ve markaya karşı büyük bir beğeni ve bağlılık sergilemektedirler. Son olarak piramidin tepesinde markanın en değerli varlıkları olan "marka evangelistleri" vardır. Bu kesim en yüksek memnuniyet seviyesindedirler ve diğer insanları da markayı beğenmeye dönüştürmek için teşvik edici konuşmalar yapma konusunda isteklidirler (Rusticus, 2006, 48-49). 
Şekil 1: Marka Evangelizmi Piramidi

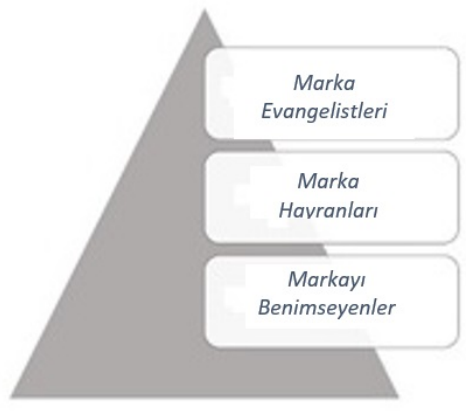

Kaynak: Rusticus, 2006: 49.

Marka evangelistlerinin bazı özellikleri bulunmaktadır (Goldfayn, 2011: 15-16);

1) Ana müşterilerdir: Diğer ana tüketicilerden oluşan bir ağla çevrili olan marka evangelistleri, markanın ürününü satmak istediği kişilerdir.

2) Tutkulu müşterilerdir: Evangelistler, ürünler hakkında yüksek bir enerji seviyesiyle düşünmekte ve konuşmaktadırlar.

3) Haber avcılarıdır: Evangelistler markanın yeni ürün sürümleri hakkında bilgi aramaktadırlar. Ürünlerin çeşitli özelliklerini arkadaşlarıyla, aileleriyle, meslektaşlarıyla, perakendecilerle ve ürünü kullanırken karşılaştıkları yabancılarla tartışmaktadırlar.

4) İletişimcilerdir: İnsanlarla ürünlerin ne kadar harika olduğu hakkında konuşmaktadırlar ve ağızdan ağıza konuşma çabalarının temelini oluşturmaktadırlar.

5) Güvenen alıcılardır: Evangelistler markaya inanma eğilimindedirler.

6) Affeden tüketicilerdir: Markaların yaptığı hataları evangelistler istenmeden meydana gelen iş kazaları olarak görmektedirler ve sorun etmemektedirler. İyi niyetli düşünmek her zaman evangelistlerin sakıncalarından daha ağır basmaktadır.

7) Aşırı tekrarlı satın alan müşterilerdir: Bazı insanlar en sevdikleri yazarlarının yazdığı her kitabı okumaktadırlar. Evangelistler, ürünleri mümkün olan en fazla sayıda satın almaktadır. Marka evangelisti, o marka bir ürün yaptığı sürece satın almaya devam etmektedir.

8) Markanın kamu savunucularıdır: Birileri markayla ilgili olumsuz şeyler konuştuğu zaman, marka evangelistleri devreye girmekte ve bu bakış açısını değiştirmeye, kötü deneyimleri gidermeye çalışmakta ve durumu pozitif bir enerjiye dönüştürmektedirler.

9) Markayla ilgili heyecan duyan müşterilerdir: Beklentilerini aşan markalarla ilgili çok yüksek bir değer algısına sahiptirler. Marka olmadan hayatı hayal edememektedirler ve onsuz nasıl yaşadıklarını merak etmemektedirler.

Kozmetik markaları üzerine 488 katılımcı ile gerçekleştirilen bir araştırmada marka evangelisti tüketicilerin; markayı satın alma niyeti ve markayı olumlu tavsiye etme üzerinde etkisi olduğu ve evangelist tüketicilerin diğer tüketiciler üzerindeki etkisinin, rakip markaların etkisinden daha fazla olduğu görülmektedir. Marka sevgisi ve marka evangelizmi olumlu ağızdan ağıza pazarlamaya yol açmaktadır. Bundan dolayı da markalar evangelist tüketicilerin etkisini daha üst düzeye çıkartacak çalışmalar gerçekleştirmelidir (Hsu, 2018: 17). Moda markalarına yönelik bir araştırmada görülmektedir ki; evangelist tüketiciler o markayı hayatının merkezine koymaktadır ve bundan dolayı da bahsi geçen markalara "merkez markalar" da denilmektedir. Dolayısıyla tüketicilerin hayatlarının merkezi olarak gördükleri markalarla ilgili evangelist tutum ve davranışlar sergilediği, etkisinin olduğu anlaşılmaktadır (Sarkar ve Sarkar, 2017: 152).

Igwe ve Nwamou; River eyaletinde 304 kişi ile otomobil konusunda yaptığı bir araştırmada marka evangelizmi ile marka sadakati arasında pozitif yönlü ve çok güçlü bir ilişki olduğunu bulmuşlardır. Marka evangelizminin marka sadakati üzerinde bir etkisi bulunmaktadır. Tüketiciler, otomobil markasını sadece fonksiyonel performans için değil, ürünün sahip olduğu ikna edici sosyal nedenlerden (evangelist konuşmalar 


\section{B. Göktaş - İ. Erdoğan Tarakçı 12/1 (2020) 126-145}

sebebiyle) dolayı satın almaktadırlar ve bu da tekrar satın alma eğilimine (marka sadakatine) dönüşmektedir. Araştırmacılar; müşterilerin sadakatini arttırma hedefi olan otomobil firmalarının, markalarının belirgin bir şekilde konumlandırılmasını, müşterilerinin kafasında ilk sıralarda yer almasını ve farklı müşterilere benzersiz anlamlar ifade edecek uygulamaların sağlanması gerektiğine vurgu yapmaktadırlar (Igwe ve Nwamou, 2017: 35-36).

Shaari ve Ahmad 2016 yılında Malezya'da 384 katılımcı ile gerçekleştirdikleri çalışmada, marka uyumunun ve marka bağlılığının marka evangelizmi üzerinde olumlu bir etkisinin olduğunu ve bunu yaparken de sadece ilgi duyulan markayla ilgili konuşulduğunu, rakip markaları kötüleyecek sözlerden kaçınıldığını (başka markaları kınamadan yapıldığını) ortaya koymuşlardır. Bunun Malezya'nın kültürel özelliklerinden kaynaklı olabileceğini düşünmüşlerdir (Shaari ve Ahmad, 2016: 87). Marticotte vd., ise 2016 yılında PlayStation veya Xbox gibi oyun konsollarına sahip olan 809 katılımcı ile yaptıkları araştırmada evangelist tüketicilerin Shaari ve Ahmad'ın aksine rakip markalara zarar verme arzusunda olduklarını ve rakip markalar hakkında olumsuz şeyler konuşma isteğinde ve davranışında bulunduklarını saptamışlardır. Araştırma sonuçlarına göre; bir müşterinin evangelist yanı ne kadar güçlüyse rakip markaya zarar verme ve rakip marka hakkında daha fazla olumsuz konuşma arzusu da o derece güçlüdür (Marticotte vd., 2016: 543).

Lee ve Hsieh 2016 yılında, sosyal sermayenin marka evangelizmine dönüşmesinde bir etkisi olup olmadığını görmek amacıyla gerçekleştirdikleri araştırmalarında, sosyal sermayenin marka aşkına, marka evangelizmine yol açtığını ve marka evangelizmi derecesinin gelişmesine etkisi olduğunu, marka evangelizmini kolaylaştırdığını, marka hayranlığ yaratmada büyük etkisi olduğunu ortaya koymuşlardır. Araştırmacılar özetle sosyal sermaye ölçeğine ait 3 faktöründe (yapısal sermaye, ilişkisel sermaye ve bilişsel sermaye) marka aşkının oluşmasında etkisi olduğunu ve marka aşkının da marka evangelizminin oluşmasında etkisinin olduğunu saptamışlardır (Lee ve Hsieh, 2016: 8). Marka sevgisi ya da marka evangelizmi; bir markaya karşı olumlu duygular besleyen ve bunun sonucu olarak da markaya yönelik duygusal bağlanmaya yol açan, kişinin o markayla ilgili tutum ve davranışlarını son derece olumlu yönde olacak şekilde yönlendiren bir eylemdir (Bauer vd., 2007: 2190).

Hassan vd., Pakistan İslamabad Üniversitesi'nin 18-32 yaş arasında değişen öğrenci ve çalışanlarına yönelik gerçekleştirdikleri çalışmalarında; müşteri hizmetlerini ve kaliteli ürünleri geliştirilen markaya duyulan güven ve marka bilinirliği değişkenlerin müşterileri evangelist hale dönüştürmede önemli bir etkisi olduğunu gösterdiğini ortaya koymaktadırlar. Sonuçlar marka sevgisinin; farklılaştırılmış müşteri hizmetleri, marka belirginliği ve marka evangelizmi arasındaki ilişkiyi yönettiğini göstermekteyken; marka bağlılı̆̆ı ile marka savunuculuğu arasındaki ilişkinin anlam düzeyinin yeterince yüksek olmadığı da görülmüştür. Dolayısıyla marka evangelizminin oluşmasında marka bağlılığı etkili değildir sonucu ortaya çıkmıştır (Hassan vd., 2016: 237). Ancak Riorini ve Widayati 2015 yılında (1 yıl önce) bankacılık hizmetleri üzerine yaptıkları bir araştırmada; marka ilişkileri, marka güveni, marka içerikleri, marka özdeşleşme ve marka bağlılığının marka evangelizmine yol açtığına ve bu faktörler arasında en etkili olanının da marka bağlllığı faktörü olduğuna dair belirtiler sunmuşlardır (Riorini ve Widayati, 2015: 41). Elde edilen bu sonuç ile Hassan vd.'nin elde ettikleri sonuçlar zıtlık göstermektedir.

Doss 2013 yılındaki çalışmasında marka özdeşleşme, marka belirginliği, marka güveni ve fikir liderliği faktörlerinin marka evangelizmine yol açtığını; fakat marka memnuniyetinin yol açmadığını belirtmektedir. Ancak marka memnuniyeti, marka özdeşleşmenin marka evangelizmi oluşturmasında bir aracılık görevi görmektedir (Doss, 2013: 6-7). Doss ve Carstens 2014 yılında "beş büyük kişilik özelliği" olarak adlandırılan "dışadönüklük, yumuşak başlılık, özdenetim, nörotizm ve deneyime açılık" faktörlerinin marka evangelizmi ile olan ilişkisini sınamaya yönelik olarak yaptığı çalışmasında marka evangelizminin dışa dönüklük, deneyime açıklık ve nörotizm faktörleri ile ilişkisi olduğunu; ancak diğer iki faktörle ilişkisi olmadığını ortaya koymaktadırlar (Doss ve Carstens, 2014: 19).

Becerra ve Badrinarayanan 2013 yılında yaptıkları marka güveni ve marka özdeşleşmenin marka evangelizmi üzerindeki etkisine yönelik çalı̧̧malarında, marka evangelizmine ait üç faktör elde etmişlerdir ve marka güveni ve marka özdeşleşmenin bu elde edilen üç faktör üzerindeki etkisine yönelik sinamalar gerçekleştirmiş̧lerdir. Sınama sonucunda marka güveninin üç faktörden ikisi üzerinde (marka satın alma niyeti ve olumlu marka tavsiyeleri); marka özdeşlemenin de üç faktörün tümü üzerinde (marka satın alma niyeti, olumlu marka tavsiyeleri ve rakip markalar hakkında olumsuz tavsiyeler) etkisi olduğu görülmüştür 


\section{B. Göktaş - İ. Erdoğan Tarakçı 12/1 (2020) 126-145}

(Becerra ve Badrinarayanan, 2013: 377). Aynı şekilde Albert vd., 2013 yılındaki çalışmalarında (1505 katılımcı ile gerçekleşen) marka güveni ve marka özdeşleşmenin marka evangelizmi üzerindeki etkisini sınamışlardır ve marka evangelizminin marka güveni ve marka özdeşleşme unsurlarına bağlı olduğunu göstermişlerdir (Albert vd., 2013: 908).

Marka evangelizmiyle, benlik-marka imajı uyumu ve marka sadakati arasında pozitif doğrusal yönlü bir ilişki ve bunun yanı sıra da marka sadakatinin benlik-marka imajı uyumu ve marka evangelizmi ilişkisinde kısmi aracılık etkisi bulunmaktadır. Bundan dolayı da benlik-marka imajı uyumu sağlandığında sadık marka müşterileri bir karşılık beklemeden markayı tanıtan, yayan evangelist davranışlar sergilemektedir (Balıkçıŏlu ve Oflazoğlu, 2015: 19). Marka güveninin, marka imajı ve marka evangelizmi ile arasındaki ilişkiye yönelik; marka sadakatinin de marka imajı ve marka evangelizmi arasındaki ilişkiye yönelik kısmi aracı etkisi bulunmaktadır. Marka imajı ile marka evangelizmi arasında anlamlı bir ilişkinin varlı̆̆ı söz konusudur ve müşteri ile güvene dayalı bir ilişki ve müşteri sadakatinin arttırılması ile bahsi geçen ilişki daha da güçlü hale gelebilmesi mümkün görülmektedir (Yılmaz ve Aykaç, 2018: 53).

Bir markadan memnun olan müşteriler başkalarıyla pozitif deneyimler paylaşmakta ve böylece markanın yapacağı pazarlama eylemlerinin de ötesinde hareket ederek markaların pazarlama eylemleri konusundaki beklentilerini karşılayabilmektedirler. $\mathrm{Bu}$ tarz müşterilere marka evangelisti denmektedir. Marka evangelistleri sadece olumlu bir ağızdan ağıza pazarlama yapmakla kalmaz, aynı zamanda diğer müşterileri rakip markaları satın almaktan vazgeçirme noktasına getirmektedir. Bir markanın evangelist tüketiciler yaratmasında müşteri memnuniyeti çok önemlidir (Rashid ve Ahmad, 2014: 401). Müşteri memnuniyeti seviyesi arttıkça, müşterinin davranışsal ve duygusal sadakatini ve savunuculuğunu da olumlu yönde etkiler. (Chaffey ve Ellis Chadwick 2012, 336). Rashid vd., 338 kişi ile yaptıkları araştırmada müşterileri memnun eden bir hizmet anlayışının marka evangelizmi üzerinde olumlu yönde bir etkisi olduğunu belirtmektedirler. Mükemmel bir hizmet gören müşteriler marka ile ilgili olumlu davranışlar sergileme eğilimindedirler ( Rashid vd., 2017: 2866).

Arkonsuo ve Leppiman 2015 yılında Z kuşağı üzerinde yaptıkları bir araştırmada, katılımcıların marka deneyimlerini anlatma eğiliminde olduklarını vurgulamaktadırlar. $Z$ kuşağı özellikle sosyal ağlar üzerinden olumlu deneyimleri ile ilgili koşmaya (pozitif ağızdan ağıza pazarlama) meyilli oldukları ve sevgi besledikleri markalarla ilgili düğer kişileri satın alma konusunda ikna etmeye hevesli olduklarını, marka sözcülüğü yaptıklarını belirtmektedirler. Bu kişiler örneğin Samsung'a olan sadakatini vurgulamaktadırlar ve de dahası Samsung'un telefonlarını birçok arkadaşına "gerçekten bir tane almaya ikna edebilmek" için anlatmaktadırlar (Arkonsuo ve Leppiman, 2015: 39-40). Fueller vd., 2012 yılında yaptıkları araştırmada; bir markanın sosyal ağ değerinin ve algılanan kalitesinin evangelist tüketiciler yarattığını ve bu tüketicilerin markayı daha yüksek bir fiyatla alma konusunda istekli olduklarına dair bulgular sunmuşlardır (Fueller vd., 2012: 3324). Sosyal ağlar, marka sadakatini geliştirmek ve marka evangelisti oluşturmak için hayati bir platformdur. Sosyal ağlar, genç hedef kitlesine ve ötesine yönelik temel eğlence ve bilgi kaynağı olduğundan, marka sadakatini ve marka evangelizmini teşvik etme gücü gözden kaçırılmamalı veya küçümsenmemelidir (Savage, 2012: 84).

\section{Yöntem}

\subsection{Araştırmanın Amacı, Yöntemi ve Kısıtları}

Daha önceden de bahsedildiği gibi marka evangelizmi kavramına yönelik alanyazın halen gelişmeye devam etmekte ve Türkiye'de de bu konuda çok az çalışma yapılmış durumdadır. Bu çalışma ile alanyazına katkı sunmak ve pazarlama yöneticilerinin dikkatini çekmek amaçlanmaktadır. Bu doğrultuda çalışmada; marka evangelizminin satın alma bağımlılığı, satın alma niyeti ve tavsiye etme üzerindeki etkisi belirlenmeye çalışılmaktadır ve bunu görebilmek için de spor kulüpleri taraftarları seçilmiş ve taraftarların tuttukları takımın ürünleri (taraftar ürünleri) konusundaki tutum ve davranışları anlaşılmaya çalışılmaktadır. Doğal olarak çalışmada spor kulüpleri birer marka olarak görülmekte ve taraftarların kulübe karşı ne derece evangelist oldukları öncelikle görülmeye çalışılmaktadır. Sonrasında da taraftarların evangelistlik seviyelerinin taraftar ürünlerini satın alma bağımlılığı yaratıp yaratmadığı ya da satın alma niyeti oluşturup oluşturmadığı ve taraftar ürünleri hakkında çevredekilere tavsiyede bulunup bulunmadığı ortaya çıkartılmak istenmektedir. 


\section{B. Göktaş - İ. Erdoğan Tarakçı 12/1 (2020) 126-145}

Çalışma önceden yapılan çalışmaların genelinden farklı olarak tasarlanmıştır. Yapılan birçok çalışmada ağızdan ağıza pazarlamanın, marka sadakatinin (brand loyalty), marka bağllığının (brand community) marka memnuniyetinin marka evangelizmi üzerindeki etkisi sınanmıştır. Elbette ki marka evangelizminin bahsi geçen kavramlar üzerindeki etkisine yönelik araştırmalar da mevcuttur. Fakat yapılan bu çalışmalarda belli markalar seçilmişken (cep telefonu, kozmetik ürünlere ait markalar gibi); eldeki çalışmada bir marka olarak katılımcıların tuttukları takımlar seçilmiş ve taraftarlar evangelist mi ve eğer evangelist ise bu durum satın alma bağımlılığı, satın alma niyeti ve tavsiye etmeye yol açabilmekte midir? Sorusuna yanıt aranmaktadır. Çalışmada hem satın alma bağımlılığına hem de satın alma niyetine yönelik önermelerin geliştirilmesindeki sebep; öncelikle taraftarın evangelistlik derecesi taraftar ürünlerini satın alma noktasında bir bağımlılık yaratmakta mıdır? Sorunun cevabını alabilmektir. Eğer satın alma bağımlılığı yaratmamakta ise bu kez en azından satın alma niyetleri konusundaki tutum ve davranışları üzerinde etkili midir? Bunu tespit edebilmektir.

Araştırmanın yöntemi olarak da bir anket hazırlanmış ve "kolayda örnekleme yöntemi" kullanılarak uygulamaya konmuştur. Anketler bir web sitesi üzerinden oluşturulmuş ve elde edilen linkin e-posta atılması, sosyal medya üzerinden gönderilmesi yoluyla doldurulması sağlanmıştır. Toplamda 707 anket doldurulmuş; ancak 614 adedi eksiksiz olduğundan değerlendirmeye alınmıştır. Anket 05.06.2019-14.06.2019 tarihleri arasında gerçekleştirilmiş olup SPSS 25 paket programında sınaması yapılmıştır. Anket demografik sorular, diğer betimsel sorular ve ölçek önermeleri olmak üzere üç kısımdan meydana gelmiştir. Ölçek önermeler oluşturulurken; tüketicilerin evangelistlik seviyelerini ölçmek için Yüksekbilgili'nin 2017 yllında Dwyer, Greenhalgh ve LeCrom tarafından 2015 yılında İngilizce olarak geliştirilen Spor Takımı Evangelizmi (Fangelizm) ölçeğinin Türkçe'ye uyarladığı Spor Takımı Evangelizmi (eFANgelizm) ölçeğinden faydalanılmıştır. Satın alma bağımlılığı ölçeği ifadeleri Bozdağ ve Alkar'ın 2018 yılında (Andreassen, Griffiths, Pallesen, Bilder, Torsheim ve Aboujaoude tarafından 2015 yılında geliştirilen Bergen Alışveriş Bağımlılığı Ölçeği'nin Türkçe'ye uyarlanmış hali) uyarladığı ölçekten alınmıştır. Satın alma niyeti ölçeği önermeleri için Bozyiğit ve Karaca (2016) ile Savaş ve Günay'ın (2016) çalışmalarından yararlanılmıştır. Tavsiye etme ölçeği önermeleri için ise; De Matos, Vargas, Teixeira ve Vieira (2009) ile Jones ve Reynolds'ın (2006) çalışmalarından faydalanılmıştır. Katılımcılara ankette 7 betimsel ve 38 ölçek önerme olmak üzere toplamda 45 soru yöneltilmiştir. Ölçek önermeleri 5'li Likert ölçeği tarzı (5: kesinlikle katılıyorum, 1: kesinlikle katılmıyorum) sunulmuş olup, bazı önermeler anketin güvenilirliğini arttırmak amacıyla tersten yöneltilmiştir. Bu önermeler daha sonra SPSS 25 paket programında tersten kodlanmıştır.

Araştırmanın kısıtları olarak; ilk kısıt katılımcılara önermeler yöneltilirken lisanslı taraftar ürünleri üzerinden yöneltilmiştir. Ancak eğer sadece taraftar ürünleri için (lisanslı ya da lisanssız) yöneltilmiş olaydı daha farklı, daha yüksek sonuçlar çıkabilirdi. İkinci kısıt ise örneklem sayısıyla alakalıdır. Araştırmada 614 anket değerlendirmeye alınmıştır. Daha fazla kişi ile yapılabilecek bir anket ile daha farklı sonuçlar ortaya çıabilirdi. Üçüncü bir kısıt ise araştırma "kolayda örneklem yöntemi" ile yapılmıştır. Ancak araştırmada katılımcı seçimi daha spesifik olsaydı, misal olarak doğrudan taraftar gruplarına yönelik (ultrAslan, çArşı, GFB, Vira, Kurukafalar, Yiğidolar, Çotanaklar, Yalı, Texas, Nefer gibi) gerçekleştirilseydi (kuvvetli ihtimal daha yüksek sonuçlar) daha farklı sonuçlar çıabilirdi. Ancak bu yöntemle de rastgele seçilmiş olan katılımcıların evangelist tutumları ve bunun yansımaları görüldüğü için bu durum aynı zamanda olumlu bir durum olarak da görülebilir. Araştırmada son bir kısıt olarak; marka evangelizmi ölçeği, eFANgelizm ölçeği zaten benzer ifadeler içermekte olduğundan (zaten marka evangelizmi ölçeğinden türediğinden) araştırmaya konulmamıştır. Bu durum bir kısıt olarak buraya konulmasına rağmen yine de bir kısıt olarak görülmemesi gerektiği düşünülmektedir.

\subsection{Araştırmanın Hipotezleri}

Araştırmanın hipotezleri, araştırma amacına uygun olarak tasarlanmıştır. Araştırmanın amacını ve temel hipotezlerini aşağıdaki şekil ile ifade etmek uygun olacaktır. Araştırmada kullanılan ölçeklerin her biri faktör analizinde tek bir faktör olacak şekilde oluşturulduğundan (faktör analizi kısmında ayrıca bahsedilecektir) araştırmanın temel hipotezlerinin altında harici hipotezler kurulmamıştır. Fakat betimsel sorulara ait gruplar arasında anlamlı bir farklılık olup olmadığını görebilmek amacıyla başka hipotezler oluşturulmuş olup bu hipotezler "grupların karşılaştırılması" başlığı altında sunulmuştur. 
Şekil 2: Araştırmanın Temel Hipotezleri

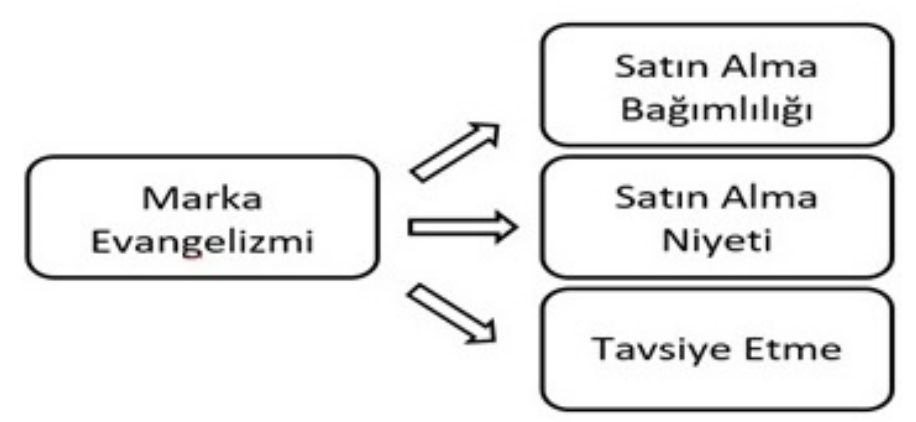

Araştırmanın temel hipotezleri;

H1: Marka evangelizminin satın alma bağımlılı̆̆ı üzerinde olumlu bir etkisi bulunmaktadır.

H2: Marka evangelizminin satın alma niyeti üzerinde olumlu bir etkisi bulunmaktadır.

H3: Marka evangelizminin tavsiye etme üzerinde olumlu bir etkisi bulunmaktadır.

\subsection{Araştırmanın Güvenilirliği ve Faktör Analizi}

Araştırmada kullanılan ölçeklerin güvenilirliğini görebilmek amacıyla Cronbach's Alfa Katsayısı'na bakılmıştır. Bu katsayının 0,81-1,00 (0,81 $\leq \alpha \leq 1,00)$ arasında olması ise ölçeğin yüksek düzeyde güvenilir olduğu anlamına gelmektedir (Kılıç, 2016: 48). Marka evangelizmi ölçeği yerine kullanılan "eFANgelizm" ölçeğinde kullanılan 12 önerme için Cronbach's Alfa Katsayısı 0,945; 9 önermeden oluşan "satın alma bağımlılığı" ölçeği için 0,958; 10 önermeden oluşan "satın alma niyeti" ölçeği için 0,958 ve 7 önermeden oluşan "tavsiye etme" ölçeği için 0,957'dir. Araştırmada kullanılan dört ölçeğin de Cronbach's Alfa Katsayısı 0,81$1,00(0,81 \leq \alpha \leq 1,00)$ arasında olduğundan ölçekler yüksek düzeyde güvenilirliğe sahiptir.

Faktör analizine gelince; analiz yapılmadan önce ölçeğin Bartlet'in küresellik testi ve KMO (Kaiser-MeyerOlkin) testi ile sinamaya uygunluğu ölçülmüştür. Bu ölçme sonucu; "eFANgelizm" ölçeği için KMO değeri 0,905 ve Bartlet'in küresellik testi yaklaşık ki karesi 6320,232 ve p değeri 0,000; "satın alma bağımlılığı" ölçeği için KMO değeri 0,912 ve Bartlet'in küresellik testi yaklaşık ki karesi 6611,737 ve p değeri 0,000; "satın alma niyeti" ölçeği için KMO değeri 0,929 ve Bartlet'in küresellik testi yaklaşık ki karesi 5856,475 ve p değeri 0,000; "tavsiye etme" ölçeği için KMO değeri 0,903 ve Bartlet' in küresellik testi yaklaşık ki karesi 4870,555 ve p değeri $0,000$ 'dır. Bu sonuçlara göre örneklem büyüklüğü yeterlidir (KMO değerleri $>0,6)$ ve önermeler birbiriyle ilişkilidir (Bartlet'in küresellik testi için $p<0,05$ ). Faktör analizi sonucu kullanılan ölçeklerin faktör yükleri Tablo 1'deki gibidir. Marka evangelizmi ölçeği yerine kullanılan eFANgelizm ölçeği aslına uygun olarak tek faktör altında toplanmıştır. Bunun yanı sıra diğer ölçeklerde de önermeler tek faktör altında toplanmıştır ve bu faktörler ölçeklerle aynı adla adlandırılmıştır. Böylece faktör isimleri de alanyazınla uyumlu olmuştur. 
Tablo 1: Araştırmada Kullanılan Ölçeklerin Faktör Yükleri ve Açıkladıkları Varyans

\begin{tabular}{|c|c|c|}
\hline eFANgelizm ölçeği önermeleri & $\begin{array}{c}\text { Faktör } \\
\text { yükü }\end{array}$ & $\begin{array}{c}\text { Toplam } \\
\text { açıklanan } \\
\text { varyans (\%) }\end{array}$ \\
\hline $\begin{array}{l}\text { 1. Tuttuğum takımdan "biz” şeklinde bahsederim. } \\
\text { 2. Çevremdekiler tuttuğum takımın iyi oyuncularından bahsederim. } \\
\text { 3. Tuttuğum takım ile ilgili tanımadığım kişilerin konuşmalarına dâhil } \\
\text { olurum. } \\
\text { 4. Aracımda tuttuğum takımı belirten ürünler bulunur. } \\
\text { 5. Ofisimde tuttuğum takımı belirten ürünler bulunur. } \\
\text { 6. Doğum günlerinde, özel günlerde tuttuğum takıma ait ürünleri hediye } \\
\text { olarak veririm. } \\
\text { 7. İnternet profillerimde tuttuğum takımı belirtirim. } \\
\text { 8. Tuttuğum takımı tutmayan arkadaşlar ve aile üyeleri ile onların tuttuğu } \\
\text { takım kaybettiğinde iletişim kurarım. } \\
\text { 9. Tuttuğum takımı tutmayan arkadaşlar ve aile üyeleri ile onların tuttuğu } \\
\text { takım kazandığında iletişim kurarım. } \\
\text { 10. Tuttuğum takımı tutmayan arkadaşlar ve aile üyeleri ile onların tuttuğu } \\
\text { takım oynarken iletişim kurarım. } \\
\text { 11. Tuttuğum takımın maçının olduğu günlerde takım üniforması giyerim. } \\
\text { 12. Aynı takımı tutan arkadaşlar ve aile üyeleri ile tuttuğumuz takım } \\
\text { oynarken iletişim kurarım. }\end{array}$ & \begin{tabular}{l|}
, 667 \\
, 798 \\
, 801 \\
, 829 \\
, 825 \\
, 806 \\
, 888 \\
, 821 \\
, 807 \\
, 807 \\
\end{tabular} & 71,867 \\
\hline Satın alma bağımlılığı ölçeği önermeleri & $\begin{array}{c}\text { Faktör } \\
\text { yükü }\end{array}$ & $\begin{array}{c}\text { Toplam } \\
\text { açıklanan } \\
\text { varyans (\%) }\end{array}$ \\
\hline $\begin{array}{l}\text { 1. Tuttuğum takımın taraftar ürünlerini satın almak hayatımdaki en önemli } \\
\text { şeydir. } \\
\text { 2. Her zaman Tuttuğum takımın taraftar ürünlerini satın almakla ilgili } \\
\text { düşünürüm. } \\
\text { 3. Bazen daha iyi hissetmek için Tuttuğum takımın taraftar ürünlerini satın } \\
\text { alırım. } \\
\text { 4. Tuttuğum takımın taraftar ürünlerini satın almak sebebiyle sevgilimi/ eşimi, } \\
\text { ailemi ve arkadaşlarımı ihmal ederim. } \\
\text { 5. Tuttuğum takımın taraftar ürünlerini satın almak konusunda kendimde } \\
\text { artan bir eğilim hissediyorum. } \\
\text { 6. Tuttuğum takımın taraftar ürünlerini satın almak konusunda } \\
\text { planladığımdan çok daha fazla alışveriş yaparım. } \\
\text { 7. Tuttuğum takımın taraftar ürünlerini satın almak konusunda gittikçe daha } \\
\text { fazla zaman harcıyorum. } \\
\text { 8. Tuttuğum takımın taraftar ürünlerini satın almayı azaltmaya yönelik } \\
\text { başarısız denemelerim oldu. } \\
\text { 9. Tuttuğum takımın taraftar ürünlerini satın almadığımda vicdanen rahatsız } \\
\text { olurum. }\end{array}$ & $\begin{array}{l}\text {,907 } \\
845 \\
839 \\
816 \\
897 \\
, 897 \\
, 893 \\
, 813 \\
, 857\end{array}$ & 75,505 \\
\hline Satın alma niyeti ölçeği önermeleri & $\begin{array}{c}\text { Faktör } \\
\text { yükü }\end{array}$ & $\begin{array}{c}\text { Toplam } \\
\text { açıllanan } \\
\text { varyans (\%) }\end{array}$ \\
\hline $\begin{array}{l}\text { 1. Tuttuğum takımın taraftar ürünlerini satın almak için çaba sarf ederim. } \\
\text { 2. Tuttuğum takımın taraftar ürünlerini satın almak için zaman harcarım. } \\
\text { 3. Tuttuğum takımın taraftar ürünlerini satın almak için bilgi toplarım. } \\
\text { 4. Tuttuğum takımın taraftar ürünlerini satın almak için istekliyim. } \\
\text { 5. Tuttuğum takımın taraftar ürünlerini pahalı olsa dahi satın alırım. }\end{array}$ & $\begin{array}{l}, 898 \\
, 877 \\
, 889 \\
910 \\
, 939 \\
, 822\end{array}$ & 75,340 \\
\hline
\end{tabular}




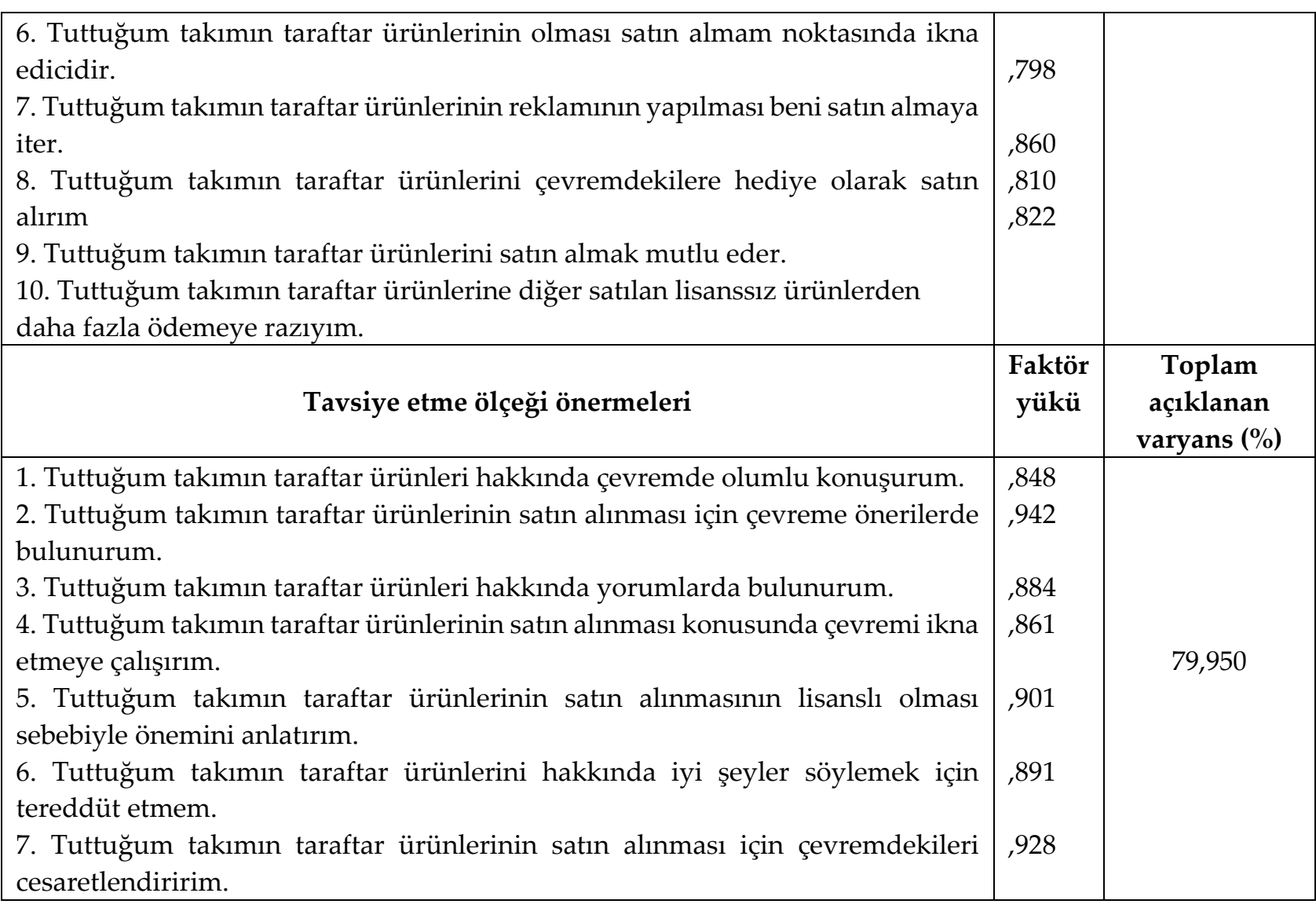

\section{Bulgular}

Bulgular kısmında demografik özellikler ve diğer betimsel soru hakkında bilgi verilmekte, gruplar arasında anlamlı farklılıklar olup olmadığı sınanmakta ve son olarak da araştırmanın temel hipotezlerine ilişkin regresyon sinaması yapilmaktadır.

Yapılan normallik testi sonucu p değeri 0,000 çıkmıştır (yani normal dağılıma uygun değildir); fakat çarpıklık ve basıklık katsayıları -1,5 ile + 1,5 arasında değerlere sahip olduğundan normal dağılıma uygun olduğu varsayılmıştır ve parametrik testler uygulanmıştır (Demir vd., 2016: 133).

\subsection{Demografik ve diğer betimsel bulgular}

Araştırmaya katılan 614 kişiden \%42'si kadın; \%58'i erkektir. Bekârların oranı \%55,2; evlilerin oranı \%44,8'dir. Yaş aralığı bakımından en fazla orana \%32,1 ile 25-34 yaş arası; eğitim durumu bakımından ise \%42,3 ile lisansüstü yer almaktadır. Meslek bakımından katılımcıların \%38,9'u uzmanlık gerektiren işlere sahipken; \%21,3'ü €5001-7000 gelire sahiptir.

Tablo 2: Örneklemin Demografik Özellikleri

\begin{tabular}{|c|c|c|c|}
\hline DEĞİŞKEN & GRUPLAR & FREKANS & $\mathbf{\%}$ \\
\hline \multirow{2}{*}{ CİNSİYET } & KADIN & 258 & 42 \\
\cline { 2 - 4 } & ERKEK & 356 & 58 \\
\hline \multirow{2}{*}{ MEDENİ HAL } & BEKÂR & 339 & 55,2 \\
\hline \multirow{3}{*}{ YAŞ ARALIĞI } & EVLİ & 275 & 44,8 \\
\cline { 2 - 4 } & $18-24$ & 182 & 29,6 \\
\cline { 2 - 4 } & $25-34$ & 197 & 32,1 \\
\cline { 2 - 4 } & $35-44$ & 173 & 28,2 \\
\cline { 2 - 4 } & $45-54$ & 10 & 8,5 \\
\cline { 2 - 4 } & +55 & & 1,6 \\
\hline
\end{tabular}


B. Göktaş - İ. Erdoğan Tarakçı 12/1 (2020) 126-145

\begin{tabular}{|c|c|c|c|}
\hline \multirow{6}{*}{ EĞİTIMM DURUMU } & İLKOKUL & 5 & 8 \\
\hline & ORTAOKUL VE DENGİ & 10 & 1,6 \\
\hline & LİSE & 17 & 2,8 \\
\hline & ÖN LİSANS & 103 & 16,8 \\
\hline & LİSANS & 219 & 35,7 \\
\hline & LİSANSÜSTÜ & 260 & 42,3 \\
\hline \multirow{9}{*}{ MESLEK } & İŞÇİ-ÇİFTÇİ & 21 & 3,4 \\
\hline & MEMUR & 107 & 17,4 \\
\hline & ÖĞRENCİ & 128 & 20,8 \\
\hline & EV KADINI & 10 & 1,6 \\
\hline & YÖNETİCI் & 25 & 4,1 \\
\hline & $\begin{array}{c}\text { UZMAN (DR., MÜHENDİS, } \\
\text { AVUKAT VS.) }\end{array}$ & 239 & 38,9 \\
\hline & ESNAF-TÜCCAR & 12 & 2 \\
\hline & İşSi̇Z & 36 & 5,9 \\
\hline & DİĞER & 36 & 5,9 \\
\hline \multirow{7}{*}{ HANE GELİR DURUMU } & $2020 €$ alt1 & 72 & 11,7 \\
\hline & $2020 €$ (asgari ücret) & 68 & 11,1 \\
\hline & 2021-3500€ & 73 & 11,9 \\
\hline & 3501-5000 き & 71 & 11,6 \\
\hline & 5001-7000 £ & 131 & 21,3 \\
\hline & 7001-9000 £ & 102 & 16,6 \\
\hline & 9001 £ ve ÜSTÜ & 97 & 15,8 \\
\hline
\end{tabular}

Katılımcılara tutukları takım da sorulmuştur. Tablo 3'de görüldüğü gibi en fazla tutulan takım \%35,26 ile Galatasaray'dır. Galatasaray'ı sırasıyla Fenerbahçe $(\% 23,77)$, Beşiktaş $(\% 22,95)$ ve Trabzonspor $(\% 10,65)$ izlemektedir. Ayrıca katılımcıların \%7,37'si de diğer seçeneğini işaretleyerek bu dört takımın haricinde bir takım tuttuklarını belirtmişlerdir.

Tablo 3: Katılımcıların Tuttukları Takım

\begin{tabular}{|c|c|c|}
\hline Takım & Frekans & \% \\
\hline Galatasaray & 217 & 35,26 \\
\hline Fenerbahçe & 146 & 23,77 \\
\hline Beşiktaş & 141 & 22,95 \\
\hline Trabzonspor & 65 & 10,65 \\
\hline Diğer & 45 & 7,37 \\
\hline
\end{tabular}

\subsection{Faktörlerin Ortalaması}

Faktörlerin ortalamasının 5'li Likert ölçeğinde sunulan 5 önermeden ortadaki rakam olan 3 rakamından büyük olması katılımcıların faktörler lehine yanıtlar verdiği anlamına gelmektedir. Ölçekte 2 ile kodlanan seçenek "katılmıyorum" seçeneğiyken; 4 ile kodlanan seçenek "katılıyorum" seçeneğidir. Bu iki seçeneğin ortasında bulunan ve 3 rakamı ile kodlanan seçenek tarafsızlık anlamına gelen "kararsızım" seçeneğidir. Tablo 4'de görüldüğü gibi “eFANgelizm” ölçeğinin ortalaması 3,6299 olup “katılıyorum” seçeneğine yakındır. Buna göre katılımcıların evangelist tutumlar sergilediği söylenebilmektedir. Ayrıca "satın alma niyeti" ve "tavsiye etme" faktörlerinin ortalaması da 3 rakamının biraz üstünde olup, bu iki faktör için katılımcıların kısmen önermeler 
B. Göktaş - İ. Erdoğan Tarakçı 12/1 (2020) 126-145

lehine yanıtlar verdiği söylenebilmektedir. Ancak "satın alma bağımlılığı" faktörüne ilişkin ortalama 3 rakamından daha düşüktür $(2,6779)$. Buna göre katılımclların bu faktöre ilişkin önermelere pek de katılmadıkları söylenebilmektedir. Fakat ortalamada standart sapmanın tüm faktörlerde yüksek olduğu da (1'in üzerinde) unutulmamalıdır.

Tablo 4: Faktörlerin Ortalaması

\begin{tabular}{|c|c|c|}
\hline Faktör & Ortalama & Standart Sapma \\
\hline eFANgelizm & 3,6299 & 1,16803 \\
\hline Satın alma bağımlılığı & 2,6779 & 1,19528 \\
\hline Satın alma niyeti & 3,2843 & 1,23119 \\
\hline Tavsiye etme & 3,2820 & 1,23707 \\
\hline
\end{tabular}

\subsection{Grupların Karşılaştırılması}

Grupların karşılaştırılması kısmında iki grubu karşılaştırmak için “bağımsız örneklem t test" ve en az üç grubu karşılaştırmak için "tek yönlü varyans analizi" sınamaları yapılmıştır.

\subsubsection{Bağımsız Örneklem T Testi}

Katılımcılara ait cinsiyet ve medeni hal değişkenlerine ait iki grup olduğu için (kadın ve erkek ile evli ve bekâr) bu iki değişken için bağımsız örneklem $t$ tesit yapılmıştır ve grupların tutumlarında anlamlı bir farklılık olup olmadığı görülmeye çalışılmıştır. Bunun için hipotezler kurulurken, gruplar arasında anlamlı bir farklılık olmadığını belirten sıfır (0) hipotezi ve tersine anlamlı bir farklılık olduğunu belirten alternatif hipotez kurulmuştur. Hipotezlerin hem istatistik bilimindeki hali sunulmuştur hem de parantez içerisinde sosyal bilimlerdekine uygun olacak biçimde açıklaması yapılmıştır. Sınamanın hipotezleri şöyledir;

Hoa: $\mu 1=\mu 2$ (Faktörlere yönelik tutumlarda gruplar arasında anlamlı bir farklılık yoktur)

$\mathrm{H}_{1 a}: \mu 1 \neq \mu 2$ (Faktörlere yönelik tutumlarda gruplar arasında anlamlı bir farklılık vardır)

Cinsiyet değişkenine ait gruplar arasında anlamlı bir farklılık olup olmadığı noktasında, tüm faktörlerde de gruplar arasında anlamlı bir farklılık olmadığı sonucu çıkmıştır. Bundan dolayı da cinsiyet değişkeni için $\mathrm{H}_{0 a}$ hipotezi reddedilememektedir. Ancak medeni hal değişkeninde "eFANgelizm" ve "satın alma bağımlılığı" faktörlerinde $\mathrm{p}<0,05$ olup bu iki faktörde gruplar arasında anlamlı bir farklılık olduğu sonucu çıkmıştır. Dolayısıyla bu iki faktör için $\mathrm{H}_{0 a}$ hipotezi reddedilebilmektedir. Grupların ortalamasına bakıldığında bekârların ortalamasının daha yüksek olduğu görülmüştür.

Tablo 5: Cinsiyet Değişkeni İçin Bağımsız Örneklem T Testi Sonuçları

\begin{tabular}{|c|c|c|c|c|c|}
\hline \multicolumn{2}{|l|}{ Faktörler } & \multicolumn{2}{|c|}{ Levene Testi } & \multicolumn{2}{|c|}{ t Testi } \\
\hline & & $\mathbf{F}$ & $\mathbf{P}$ & $\mathbf{t}$ & $\mathbf{P}$ \\
\hline \multirow[t]{2}{*}{ eFANgelizm } & V.e.v & \multirow[t]{2}{*}{8,034} & \multirow[t]{2}{*}{005} & $-1,816$ &, 070 \\
\hline & V.e.o.v & & & $-1,838$ &, 067 \\
\hline \multirow[t]{2}{*}{ Satın alma bağımlılı̆ğ } & V.e.v & \multirow[t]{2}{*}{261} & \multirow[t]{2}{*}{ 610 } & ,453 & ,651 \\
\hline & V.e.o.v & & &, 450 & ,653 \\
\hline \multirow[t]{2}{*}{ Satın alma niyeti } & V.e.v & \multirow[t]{2}{*}{, 160 } & \multirow[t]{2}{*}{689} &,- 997 & ,319 \\
\hline & V.e.o.v & & &,- 986 & ,325 \\
\hline \multirow[t]{2}{*}{ Tavsiye etme } & V.e.v & \multirow[t]{2}{*}{063} & \multirow[t]{2}{*}{, 802} & ,233 & ,816 \\
\hline & V.e.o.v & & & ,232 & ,817 \\
\hline
\end{tabular}




\subsubsection{Tek Yönlü Varyans Analizi}

Tek yönlü varyans analiziyle; yaş, eğitim, meslek, gelir ve tutulan takım değişkenlerine ait gruplar arasında anlamlı bir farklılık olup olmadığı sınanmaktadır. Sınamanın hipotezleri şöyledir;

Hob: $\mu 1=\mu 2=\mu 3=\mu 4=\mu 5$ (Faktörlere yönelik tutumlarda gruplar arasında anlamlı bir farklılık yoktur)

$\mathrm{H}_{1 b}$ : $\mu j^{\prime}$ lerden en az biri diğerlerinden farklıdır (Faktörlere yönelik tutumlarda gruplardan en az birinde, diğer gruplarla arasında anlamlı bir farklılık vardır)

Yaş değişkenine ait gruplarım tutumlarında, faktörlerin tümünde anlamlı bir farklılık çıkmıştır. Dört faktör için de $\mathrm{p}<0,05^{\prime}$ dir. Buna göre yaş değişkeni için Hob hipotezi reddedilebilmektedir. Bu farklılık 18-24, 25-34, 3544 yaşları arasında olup 18-24 yaş aralığının ortalaması daha fazladır. Eğitim değişkeninde de tüm p değerleri 0,05'den küçüktür ve $\mathrm{H}_{0 b}$ hipotezi reddedilebilmektedir. Post Hoc sınamasında bu anlamlı farklılığın lise ile ön lisans, lisans ve lisansüstü grupları arasında olduğu dikkat çekmiştir. Meslek değişkenin de de yine tüm faktörlerde $\mathrm{p}<0,05$ olup $\mathrm{H}_{0 \mathrm{~b}}$ hipotezi reddedilebilmektedir. En dikkat çeken anlamlı farklılık memur ile öğrenci arasında olup öğrencinin ortalaması daha yüksektir. Hane gelir düzeyi bakımından da yine $\mathrm{H}_{0 b}$ hipotezi reddedilebilmektedir. Çünkü tüm p değerleri 0,05'den küçüktür. €2020'den az gelire sahip olan grup ile diğer tüm gruplar arasında anlamlı bir farklılık olup £2020'den az gelire sahip olan grubun ortalaması daha düşüktür. Katılımcıların tuttukları takım değişkeni için de sonuç aynı olup Hob hipotezi reddedilebilmektedir. Özetle tek yönlü varyans analizi için yapılan sınamaların tümünde $\mathrm{H}_{0 \text { b }}$ hipotezi reddedilebilmekte ve "faktörlere yönelik tutumlarda gruplardan en az birinde, diğer gruplarla arasında anlamlı bir farklılık vardır" denilebilmektedir.

Tablo 6: Katılımcıların Tuttukları Takım Değişkeni İçin Tek Yönlü Varyans Analizi Sonucu

\begin{tabular}{|c|c|c|c|c|c|c|}
\hline \multicolumn{2}{|c|}{ Faktörler } & \multirow{2}{*}{\begin{tabular}{|c|}
$\begin{array}{c}\text { Kareler } \\
\text { Toplamı }\end{array}$ \\
66,546 \\
\end{tabular}} & \multirow{2}{*}{\begin{tabular}{|c|}
$\begin{array}{c}\text { Serbestlik } \\
\text { Derecesi }\end{array}$ \\
4 \\
\end{tabular}} & \multirow{2}{*}{$\begin{array}{c}\text { Ortalama } \\
\text { Kare }\end{array}$} & \multirow{2}{*}{$\begin{array}{c}\text { F } \\
\text { Değeri } \\
16,013\end{array}$} & \multirow{2}{*}{\begin{tabular}{|c|}
$\begin{array}{c}\mathbf{P} \\
\text { Değeri }\end{array}$ \\
, 000
\end{tabular}} \\
\hline eFANgelizm & Gruplar Arasında & & & & & \\
\hline & Gruplar İçerisinde & 632,700 & 609 & 1,039 & & \\
\hline & Toplam & 699,246 & 613 & & & \\
\hline \multirow{3}{*}{ Satın alma bağımlılığı } & Gruplar Arasında & 58,351 & 4 & 14,588 & \multirow[t]{3}{*}{16,186} & \multirow[t]{3}{*}{,000 } \\
\hline & Gruplar İçerisinde & 548,870 & 609 & ,901 & & \\
\hline & Toplam & 607,221 & 613 & & & \\
\hline \multirow{3}{*}{ Satın alma niyeti } & Gruplar Arasinda & 72,509 & 4 & 18,127 & \multirow[t]{3}{*}{15,508} & \multirow[t]{3}{*}{,000 } \\
\hline & Gruplar İçerisinde & 711,879 & 609 & 1,169 & & \\
\hline & Toplam & 784,388 & 613 & & & \\
\hline \multirow{3}{*}{ Tavsiye etme } & Gruplar Arasinda & 84,035 & 4 & 21,009 & \multirow[t]{3}{*}{18,058} & \multirow[t]{3}{*}{,000 } \\
\hline & Gruplar İçerisinde & 708,528 & 609 & 1,163 & & \\
\hline & Toplam & 792,563 & 613 & & & \\
\hline
\end{tabular}

\subsection{Regresyon analizi}

Regresyon analizi ile bağımsız değişkenin bağımlı değişken üzerindeki etkisi görülmeye çalışmıştır. Kurulan modellerde bağımsız değişkendeki nispi değişimin bağımlı değişkende nasıl bir değişime yol açtığı görülmektedir. Regresyon analizinde modelin açıklama gücü ve etki katsayısına yönelik hipotezler istatistik bilimindekine uygun olarak aşağıda sıralandığı gibidir;

Modelin açıklama gücüne (belirlilik katsayısı) yönelik hipotezler;

$$
\begin{aligned}
& H_{0}: R^{2}=0 \\
& H_{1}: R^{2}>0
\end{aligned}
$$


Etki katsayısına (regresyon katsayısı) yönelik hipotezler;

$$
\begin{aligned}
& \mathrm{H}_{0}: \beta=0 \\
& \mathrm{H}_{1}: \beta \neq 0
\end{aligned}
$$

Gerçekleştirilen araştırma için oluşturulmuş olan etki katsayısına yönelik temel hipotezler de önceden de belirtildiği gibi şöyledir;

H1: Marka evangelizminin satın alma bağımlılığı üzerinde olumlu bir etkisi bulunmaktadır.

$\mathrm{H}_{2}$ : Marka evangelizminin satın alma niyeti üzerinde olumlu bir etkisi bulunmaktadır.

$\mathrm{H}_{3}$ : Marka evangelizminin tavsiye etme üzerinde olumlu bir etkisi bulunmaktadır.

Tablo 7'ye bakıldığında kurulan üç modelde de modelin açıklama gücü oldukça yüksektir. Model 1 için R² =,569; model 2 için $\mathrm{R}^{2}=$,662; model 3 için $\mathrm{R}^{2}=, 643^{\prime}$ dür. Buna göre model $1^{\prime}$ in $\% 56,9^{\prime}$ u kurulan model ile açıklanırken; kalan kısmı $(\% 43,1)$ başka değişkenlerle açıklanmaktadır. Model 2'nin \%66,2'si kurulan model ile açıklanırken; kalan kısmı $(\% 33,8)$ başka değişkenlerle açılanmaktadır. Model 3'ün \%64,3'ü kurulan model ile açıklanırken; kalan kısmı (\%35,7) başka değişkenlerle açıklanmaktadır. Bu sonuçlara göre "modelin açıklama gücüne (belirlilik katsayısı) yönelik" hipotezlerden $\mathrm{H}_{0}$ hipotezi reddedilebilmektedir.

Kurulan modellerin $\beta$ değerlerine bakıldığında ise; model 1 için $\beta=, 703$; model 2 için $\beta=, 862$ ve model 3 için $\beta=, 854$ ' dür. Buna göre katılımcıların "eFANgelizm" faktörü konusundaki 1 birimlik tutum değişikliği "satın alma bağımlılığı" değişkeni üzerinde 0,703; "satın alma niyeti" değişkeni üzerinde 0,862; "tavsiye etme" değişkeni üzerinde 0,854 birimlik bir değişikliğe yol açmaktadır. Elde edilen bu sonuçlar neticesinde "etki katsayısına (regresyon katsayısı) yönelik" hipotezlerden $\mathrm{H}_{0}$ hipotezi reddedilebilmektedir. Bir başka deyişle eFANgelizm bağımsız değişkeninin satın alma bağımlılığı, satın alma niyeti ve tavsiye verme bağımlı değişkenleri üzerinde olumlu (tüm $\beta$ değerleri pozitif) bir etkisi bulunmaktadır. Dolayısıyla araştırmanın temel hipotezlerinin tümü kabul edilebilmektedir. Bahsi geçen sınama sonuçları aşağıdaki Tablo 7 'de sunulmaktadır.

Tablo 7: Basit Doğrusal Regresyon Analizi Sonuçları

\begin{tabular}{|c|c|c|c|c|c|c|}
\hline Model & Bağımsız Değişken & Bağımlı Değişken & $\mathbf{R}^{2}$ & $\begin{array}{c}\text { P Değeri } \\
\left(\mathbf{R}^{2}\right.\end{array}$ & $\boldsymbol{\beta}$ & $\begin{array}{c}\text { P Değeri } \\
\mathbf{(} \boldsymbol{\beta} \mathbf{)}\end{array}$ \\
\hline 1 & eFANgelizm & Satın alma bağımlılı̆̆1 &, 569 &, 000 &, 703 &, 000 \\
\hline 2 & eFANgelizm & Satın alma niyeti &, 662 &, 000 &, 862 &, 000 \\
\hline 3 & eFANgelizm & Tavsiye etme &, 643 &, 000 &, 854 &, 000 \\
\hline
\end{tabular}

Anketlere bakıldığında; evangelizm ölçeği için yüksek seçeneği işaretleyen katılımcının diğer faktörlerde de yüksek seçenekleri işaretlediği; düşüş seçeneği işaretleyenlerin diğer faktörlerde de düşük seçenekleri işaretlediği göze çarpmıştır. Örneğin 1 numaralı ankette eFANgelizm faktörü ortalaması 3,93; satın alma bağımlılığı 3,33; satın alma niyeti 4; tavsiye etme 4'tür. Buna karşın 3 numaralı ankette eFANgelizm faktörü ortalaması 1,17; satın alma bağımlılığı 1; satın alma niyeti 1,33; tavsiye etme 1'dir. Buna göre eFANgelizm faktörü ortalamasının 3,6299; satın alma bağımlılı̆̆ faktörü ortalamasının 2,6779 olmasına rağmen aralarında etki çıkması olası bir durumdur. Araştırmanın temel hipotezlerine ilişkin kararlar aşağıdaki Tablo 8'de gösterilmiştir. 
B. Göktaş - İ. Erdoğan Tarakçı 12/1 (2020) 126-145

Tablo 8: Araştırmanın Temel Hipotezlerine İlişkin Kararlar

\begin{tabular}{|l|c|}
\hline \multicolumn{1}{|c|}{ Hipotez } & Karar \\
\hline $\begin{array}{l}\text { H1: Marka evangelizminin satın alma bağımlılı̆̆ üzerinde olumlu bir etkisi } \\
\text { bulunmaktadır. }\end{array}$ & Kabul edilebilmektedir \\
\hline $\begin{array}{l}\mathrm{H}_{2}: \text { Marka evangelizminin satın alma niyeti üzerinde olumlu bir etkisi } \\
\text { bulunmaktadır. }\end{array}$ & Kabul edilebilmektedir \\
\hline $\begin{array}{l}\text { H3: Marka evangelizminin tavsiye etme üzerinde olumlu bir etkisi } \\
\text { bulunmaktadır. }\end{array}$ & Kabul edilebilmektedir \\
\hline
\end{tabular}

\section{Sonuç ve Öneriler}

Genel olarak marka evangelistleri, belirli bir markaya tutkuyla bağlı olan, coşkuyla pozitif marka deneyimini başkalarına aktaran, başkalarını aynı markayı almaya ikna eden ve rakip markanın satın alınmasını engelleyen müşterilerdir (Rashid ve Ahmad, 2014: 403). Bundan dolayı da marka evangelizmi Matzler, Pichler ve Hemetsberger tarafından olumlu görüşler yaymak ve başkalarını aynı marka ile ilişki kurmaya ikna etmek ya da ikna etmek için hararetle çalışmak olarak tanımlanmaktadır ( Matzler vd., 2007: 27). Evangelist tüketiciler markayı tanıtarak, markaya pek çok avantaj sağlamaktadırlar. En önemli sağladı̆̆ı avantaj, yapılan pazarlamadan kaynaklı bir rekabet avantajıdır. Ayrıca, marka evangelistleri, güçlü marka topluluklarının inşasına yol açabilecek övgüde bulundukları organizasyonun bir üyesi olmadıkları için güvenilirlik düzeyi sağlamaktadırlar (Dwyer vd., 2014: 263). Marka evangelistleri; marka ile ilgili konuları sosyal çevresine ileten kişilerdir ve bunlar bir markanın en sadık müşterileridir. Marka evangelistlerinin olası müşterilere sundukları iletilerle markanın doğrudan iletileri arasında çok ciddi farklar vardır. Marka evangelistleri iletileri çok daha fazla kişiselleştirebilme özelliğine sahiptir. Marka mesajlarını medya ile kitlesel olarak iletmenin yanı sıra medya dışı araçları kullansa da marka evangelisti kadar kişiselleştirememektedir. Kişiselleştirilmiş mesaj (yani hedef kitleye uyarlanmış mesaj) daha etkili ve ikna edici olmaktadır. Böylece marka evangelistleri bir kişisel satış elemanı gibi çalışmakta ve karşılığında da herhangi bir ücret almaktadır.

Bir marka evangelisti, bir işletmenin ürünleri hakkında kamuya açık alanlarda konuşmaktan çekinmeyen, herhangi bir ürünün sabit hayranıdır. Ürün bilgilerini sık sık diğer insanlarla paylaşmaktadırlar ve ürünü agresif bir şekilde tanıtmaya yardımcı olmaktadırlar. Marka evangelistinin amacı; tanıttığı markadan mal ya da para gibi maddi bir çıkar beklemeksizin gönüllü olarak, diğer müşterilere kişisel inançlarına dayanarak tavsiyelerde bulunarak onlarla markanın faydalarını paylaşmasıdır. Bundan dolayı birer marka elçisi olarak da bilinmektedirler ve bazı zamanlar sadece müşteriler değil, işletme çalışanları da marka evangelisti gibi çalışmaktadırlar (Choudhury, 2019: 1). Evangelist tüketiciler sayesinde; markayla ilgili olumlu görüşlerin diğer insanlara yayılmasıyla marka efsaneleşmekte, bu efsaneler ile de insanlar büyülenmekte ve fanatik marka takipçileri meydana gelmektedir. Bu yönüyle de evangelizm pazarlama uygulamaları büyük bir güce sahiptir (Wang vd., 2019: 736).

Çalışmada marka evangelizminin; satın alma bağımlılığı, satın alma niyeti ve tavsiye etme üzerindeki etkisi sınanmaktadır. Bu sınamayı yapabilmek amacıyla da spor kulüpleri seçilmiş ve spor kulübü taraftarlarının evangelistlik derecelerinin taraftar ürünlerini satın alma konusunda bağımlılık oluşturulmasında etkisinin olup olmadığı ya da satın alma niyeti yaratıp yaratmadığı ve bu taraftar ürünlerinin çevreye tavsiye edilip edilmediği noktasındaki etkisi görülmeye çalışılmıştır. Bunu görebilmek amacıyla da eFANgelizm ölçeği bağımsız değişken olarak; satın alma bağımlılığı, satın alma niyeti ve tavsiye etme ölçekleri de bağımlı değişkenler olarak tasarlanmıştır. Faktör analizi sonucu her bir ölçek için tek bir faktör çatısı altında toplanmıştır. Araştırmada gerçekleşen sınamada bağımsız değişkenin tüm bağımlı değişkenler üzerinde etkisi olduğu sonucu ortaya çıkmış ve bundan dolayı da araştırmanın tüm temel hipotezleri "kabul edilebilir" (H1, $\mathrm{H} 2$ ve H3 desteklenmektedir) bulunmuştur. Buna dayanarak marka evangelizminin; satın alma bağımlılığı, satın alma niyeti ve tavsiye etme üzerinde etkisi olduğu sonucu çıkarılmaktadır. Araştırma bu yönüyle alanyazın kısmında bahsedilen çalışmaların bazılarıyla (Hsu, 2018, satın alma niyeti; Igwe ve Nwamou, 2017, satın alma bağımlılığı, Arkonsuo ve Leppiman 2015, Fueller vd., 2012, tavsiye etme, Becerra ve 


\section{B. Göktaş - İ. Erdoğan Tarakçı 12/1 (2020) 126-145}

Badrinarayanan 2013, satın alma niyeti ve marka tavsiyeleri) tamamen aynı olmamakla birlikte benzerlikler göstermektedir. Çünkü eldeki çalışma bahsi geçen çalışmalarla bire bir aynı olmamakta, farklılıklar arz etmektedir. Bundan dolayı bahsi geçen çalışmaların bir kısmıyla benzeşmektedir. Çalışmanın temel kurgusu bahsi geçen çalışmalardan farklılık göstermesi sebebiyle alanyazına katkı sunmaktadır. Ayrıca Türkiye'de marka evangelizmi konusunda yapılmış olan çalışmalar oldukça kısıtlıdır. Yapılan tarama sonucunda özellikle eFANgelizm konusu ile birleştirilerek gerçekleştirilmiş bir çalışmaya rastlanmadığından, alanyazının gelişmesine olan katkısının daha da pekiştirildiği düşünülmektedir.

Günümüzde bir markanın gerçekleştirdiği pazarlama iletişimi uygulamaları taklit edilebilmektedir. Bunun yanı sıra pek çok marka aynı tür ve kaliteli ürünler de piyasaya arz edebilmektedir. Marka evangelistleri böyle bir durumda ürünü farklılaştıran bir görev üstlenmektedir. Her gün bir sürü ürünün piyasa sürüldügü, raflarda yer aldığı bir ortamda, o raftan o ürünü satın alacak olası müşterinin ikna edilmesinde marka evangelistleri kritik bir görev üstlenmektedir. Bir ürünle ilgili kitlesel yapılan bir pazarlama iletişimi çalışmasında, müşteri yoğun mesaj bombardımanı arasında boğulabilmekte, mesajı kaçırabilmektedir. Fakat marka evangelistlerinin ısrarcı yapısı ile olası müşterinin gözünden kaçan bir ürünün fark edilebilme olasılığı bulunmaktadır.

Eğer ürünün pazarlama iletişimi çalışmaları yanlış tasarlanmışsa (reklamı, ambalajı vs.) marka evangelistlerinin markadan duyduğu memnuniyeti dile getirmesi ile markalar durumu bir nebze de olsa kurtarabilir, olumsuz durumu azaltabilir. Böylece markanın başarısızlığı, evangelist müşterileri sayesinde onarılabilir. Dolayısıyla markaların pazarda rekabet edebilmesinde evangelist tüketicilere sahip olması önemli bir nokta haline gelmektedir. Evangelizm pazarlama, pazarlama yöneticileri tarafından, pazarlama stratejilerinin bir parçası olarak düşünülmelidir. Çünkü işletme evangelist tüketiciler vasıtasıyla yeni müşteriler kazanabilmekte, satışlarını arttırabilmektedir. Sonuç olarak; marka evangelistleri çıkar amacı gütmeksizin markanın pazarlamasını yapan kişiler olduğu için evangelist pazarlama oldukça saf, temiz bir pazarlama iletişimi yöntemi olmaktadır. Bundan dolayı da markaların yapması gereken, kendileriyle ilgili memnuniyetlerini dile getirecek, olası müşterilere yayacak birer marka evangelistleri kitlesi oluşturmaktır. Çünkü evangelist tüketiciler markadan bizim markamız ya da biz diye bahseden kişilerdir. Yani işletmenin markası artık markanın müşterisinin markası konumuna dönüşmüştür.

Evangelist müşteriler; markanın tutkulu müşterileridir. Bu tutku sayesinde de markanın yılmaz bir taraftarı konumuna bürünmektedir. Tutkulu müşteriler, markaya olan güven ve desteklerini çeşitli ortamlarda gösterdikleri sürece, bu durum markanın satışlarına olumlu yönde yansıyabilir bir hal alabilir. Olası müşteriler marka hakkındaki bu kadar övgüye kayıtsız kalmayabilir ve markayı deneme gereksinimi duyabilirler. Dolayısıyla markalar, bu denli markasını savunan, markanın tutkulu bir taraftarı olan evangelistleri karşılarına almak yerine, onlarla olan iletişimi devam ettirmeli ve onları gerçekleştirecekleri pazarlama faaliyetleri ile etkilemeli, sadık müşteriler olarak kalması konusunda ısrarcı olmalıdırlar.

Diğer yandan, marka evangelizminin kanıtlanmış gücü karşısında etkin bir marka yönetimi ve pazarlama iletişiminin gerekliliği de bir kez daha ön plana çıkmaktadır. Bahsedilen tüm olumlu etkilerinin yanı sıra, evangelist ruh diğer markaların sahip olduğu kusurları da dile getirmekten çekinmeyecek, kötü bir ürün tasarımı ya da kötü bir müşteri iletişimi neticesinde yaşanılabilecek olumsuz bir deneyim başka markanın aleyhine oluşumları tetikleyerek olumsuz marka birliklerinin oluşumuna neden olabilecektir. Özellikle sosyal ağlar üzerinden oldukça geniş kitlelerin birbirlerine ulaşmalarının mümkün hale geldiği günümüz teknoloji dünyasında olumsuz marka birliklerinin oluşması markaların henüz kendilerini savunmaya bile fırsat bulamayacakları bir hızda gerçekleşebilecektir. Bu noktada eğer marka; evangelist tüketici topluluğu oluşturmuşsa, bulamadığı kendisini savunma olanağını evangelistleri sayesinde yerine getirebilecektir. Bir yandan da markaların bu aşamada yapması gereken, etkin bir pazarlama iletişimi stratejisi ile etkili bir algı yönetimi uygulamalarıdır. Etkili iletişim aynı zamanda pazarlama mesajı ve dağıtım yöntemi gibi konularında marka evangelizminin markaların üzerinde yaratabileceği kontrol eksikliğinin de bir çözümü olabilecektir. 


\section{Kaynakça}

Albert, N., Dwight, M. ve Florence, P.V. (2013). Brand Passion: Antecedents and Consequences, Journal of Business Research, 66: 904-909.

Anggarini, L. (2018). Understanding Brand Evangelism and The Dimensions Involved in A Consumer Becoming Brand Evangelist, Sriwijaya International Journal of Dynamic Economics and Business, 2(1): 63-84.

Arkonsuo, R. ve Leppiman, A. (2015). Young Consumers and Their Brand Love, International Journal of Business and Social Research, 5(10): 33-44.

Arkonsuo, R., Kaljund, K. Ve Leppiman, A. (2014). Consumer Journey From First Experience To Brand Evangelism, Research in Economics and Business: Central and Eastern Europe, 6(1): 5-28.

Balıkçıŏlu, B. ve Oflazoğlu, S. (2015). Marka Evangelizmi, Benlik-Marka İmajı Uyumu ve Marka Sadakati İlişkisi Üzerine Ampirik Bir Araştırma, Tüketici ve Tüketim Araştırmaları Dergisi, 7 (2): 19-45.

Bauer, H. H., Heinrich, D., ve Martin, I. (2007). How To Create High Emotional Consumerbrand Relationships? The Causalities Of Brand Passion. In 2007 Australian And New Zealand Marketing Academy Conference Proceedings (Pp. 2189-2198).

Becerra, E.P. ve Badrinarayanan, V. (2013). The Influence Of Brand Trust And Brand Identification on Brand Evangelism, Journal of Product \& Brand Management, 22(5/6): 371-383.

Bozdağ, Y. ve Yalçınkaya Alkar, Ö. (2018). Bergen Alışveriş Bağımlılı̆̆ı Ölçeği'nin Kompülsif Çevrimiçi Satın Alma Davranışına Uyarlanması, Bağımlılık Dergisi - Journal Of Dependence, 19(2): 23-34.

Bozyiğit, S. ve Karaca, Y. (2016). Türkiye'deki Etnik Reklamlara Yönelik Tüketicinin Tutum ve Davranışlarının Değerlendirilmesi, Gümüşhane Üniversitesi Sosyal Bilimler Enstitüsü Elektronik Dergisi, 7 (15): 288307.

Cestare, T. ve Vishal Lala, V. (2015). Brand Evangelism: Model of Antecedents and Consequences, Direct/Interactive Marketing Research Summit, Boston, MA. (October 3, 2015). Https://Www.Marketingedge.Org/Sites/Default/Files/Pdf/10-Cestare-Lala.Pdf.

Chaffey, D., ve Ellis-Chadwick, F. (2012). Digital Marketing: Strategy, Implementation And Practice. 5th Edition. Edingburgh: Pearson Education.

Choudhury, M., Mishra, B.B. ve Mohanty, P.K. (2019). An Empirical Study of Brand Evangelism for Recommending Cars-A Qualitative \& Systematic Review of Literature, International Journal of Technical Research \& Science, 4 (3): 1-12.

Conley, C. ve Fishman, E.F. (2006). Marketing That Matters 10 Practices To Profit Your Business And Change The World, Berrett-Koehler Publishers; 1 Edition, Oakland, California, U.S.A

De Matos, A., Vargas, C.., Teixeira R. ve Vieira, V. (2009). Consumer Reaction To Service Failure And Recovery: The Moderating Role Of Attitude Toward Complaining. Journal Of Services Marketing, 23(7): 462-475.

Demir, E., Saatçioğlu, Ö. ve İmrol, F. (2016). Uluslararası Dergilerde Yayımlanan Eğitim Araştırmalarının Normallik Varsayımları Açısından İncelenmesi. Current Research İn Education, 2(3): 130-148.

Doss, S. K. (2013). Spreading The Good Word: Toward An Understanding Of Brand Evangelism, Journal of Management and Marketing Research, 14, 1-15.

Doss, S.K. ve Carstens, D.S. (2014). Big Five Personality Traits and Brand Evangelism, International Journal of Marketing Studies, 6 (3): 13-22.

Dwyer, B., Greenhalgh, G. ve Lecrom, C. (2014). Developing and Validating A Scale To Measure Sport Team Efangelism (TM), 2014 North American Society For Sport Management Conference (NASSM 2014), 263264. 
B. Göktaş - İ. Erdoğan Tarakçı 12/1 (2020) 126-145

Fueller, J. Schroll, R. Dennhardt, S. ve Hutter, K. (2012). Social Brand Value and The Value Enhancing Role of Social Media Relationships for Brands, 45th Hawaii International Conference on System Sciences, 3218-3227, Publisher: IEEE, DOI 10.1109/HICSS.2012.533, 4-7 Jan.

Goldfayn, A.L. (2011). Evangelist Marketing What Apple, Amazon, And Netflix Understand About Their Customers (That Your Company Probably Doesn't), Benbella Books, Inc. Dallas, Texas

Hassan, M., Rafi, A. ve Kazmi, S.S. (2016). Impact of Differentiated Customer Service, Brand Trust, Brand Commitment, and Brand Salience on Brand Advocacy, International Review of Management and Marketing, 6 (4): 232-238.

Hsu, L.C. (2018) Investigating The Brand Evangelism Effect of Community Fans on Social Networking Sites: Perspectives on Value Congruity, Online Information Review, Https://Doi.Org/10.1108/OIR06-2017 0187, 3-27.

Igwe, S.R. ve Nwamou, C.C. (2017). Brand Evangelism Attributes and Lecturers Loyalty of Automobiles in Rivers State, Covenant Journal of Business \& Social Sciences (CJBSS), 8 (2): 23-39.

Jones, M.A. ve Reynolds, K.E. (2006). The Role Of Retailer İnterest On Shopping Behavior, J Retail; 82(2):11526.

Kılıç, S. (2016). Cronbach'ın Alfa Güvenirlik Katsayısı. Journal Of Mood Disorders, 6 (1): 47-48.

Lee, C. T. ve Hsieh, S. (2016). The Effects of Social Capital on Brand Evangelism in Online Brand Fan Page: The Role of Passionate Brand Love, PACIS 2016 Proceedings. 170. http://Aisel.Aisnet.Org/Pacis2016/170 , Summer 6-27-2016, pp: 1-11.

Marticotte, F., Arcand, M. ve Baudry, D. (2016). The Impact of Brand Evangelism on Oppositional Referrals Towards A Rival Brand, Journal of Product \& Brand Management, 25(6 ): 538-549.

Matzler, K. Pichler, E. ve Hemetsberger, A. (2009). Passionate Devotees or Knowledgeable Brand Experts: Who Drives Evangelism?, American Marketing Association / Winter Educators' Conference Proceedings, February, 239-241.

Matzler, K., Pichler, E. A., \& Hemetsberger, A. (2007). Who İs Spreading The Word? The Positive İnfluence Of Extraversion On Consumer Passion And Brand Evangelism. American Marketing Association, Winter, 25-32.

Pride, W.M. ve Ferrell, O. (2016). Marketing 2016, 2nd Edition. Cengage Learning.New Mexico:

Raj, M.P.M., Sasikumar, J. ve Sriram, S. (2013). A Study on Customers Brand Preference In Suvs And Muvs: Effect Of Marketing Mix Variables, International Refereed Research Journal, 4(1): 48-58.

Rashid, M.H. ve Ahmad, S.H. (2014). The Role of Recovery Satisfaction on The Relationship Between Service Recovery and Brand Evangelism: A Conceptual Framework, International Journal of Innovation, Management and Technology, 5 (5): 401-405.

Rashid, M.H., Ahmad, F.S. ve Hasanordin, R. (2017). Creating Brand Evangelists Through Service Recovery: Evidence From The Restaurant Industry, Advanced Science Letters, 23: 2865-2867.

Riorini, S.V. ve Widayati, C.C. (2015). Brand Relationship and Its Effect Towards Brand Evangelism To Banking Service, International Research Journal of Business Studies, 8 (1): 33 - 45.

Rusticus, S. (2006). Creating Brand Advocacy. In Kirby, J., \& Marsden, P. (Eds.) Connected Marketing: The Viral, Buzz and Word of Mouth Revolution. Oxford: Elsevier, Ltd.

Schnebelen, S. ve Bruhn, M. (2018). An appraisal framework of the determinants and consequences of brand happiness, Psychology \& Marketing, 35: 101-119.

Saravanan, M. ve Saraswathy, T.R (2017). Evangelism As A Marketing Strategy- In The Challenging and Innovative Business Scenario, Intercontinental Journal of Marketing Management, 4(6): 1-5.

Sarkar, A. ve Sarkar, J. G. (2017). Validating Fashion Brand Centrality Scale Amongst Young Adults, Journal Of Fashion Marketing and Management, 21(1): 133-156. 
B. Göktaş - İ. Erdoğan Tarakçı 12/1 (2020) 126-145

Savage, J. (2012). Creating Brand Evangelists in The 21st Century: Using Brand Engagement Through Social Media To Develop Brand Loyalty in Teens, Master's Thesis, Graduate School Unıversity of Southern California:ABD.

Savaş, B. ve Günay, G. (2016). Tüketici - Tüketici Etkileşiminin, Tüketicilerin Satın Alma Sonrası Memnuniyet Düzeyleri Üzerine Etkisi, Üçüncü Sektör Sosyal Ekonomi, 51, (2) : 47 -78.

Shaari, H. ve Ahmad, I.S. (2016). Brand Evangelism Among Online Brand Community Members, International Review of Management and Business Research, 5(1): 80-88.

Shaari, H. ve Ahmad, I.S. (2016). The Effect of Brand Trust And Brand Community Commitment on Online Brand Evangelism Behaviour, Malaysian Management Journal, 20: 77-86.

Singh, N. (2015). Evangelism Marketing: The Evolution of Consumer Fidelity, Journal of Marketing 4 \& Communication, 11 (1): 3-14.

Smilansky, S. (2009). Experiential Marketing: A Practical Guide To Interactive Brand Experiences. Philadelphia: Kogan Page Ltd.

Swimberghea, K., Darratb, M.A., Beala, B.D. ve Astakhovaa, M. (2018). Examining A Psychological Sense Of Brand Community in Elderly Consumers, Journal of Business Research, 82: 171-178.

Wang, C.L., Sarkar, J.G. ve Sarkar, A. (2019). Hallowed Be Thy Brand: Measuring Perceived Brand Sacredness, European Journal of Marketing, 53 (4): 733-757.

Web: https://Tr.Scribd.Com/Document/28989043/Evangelism-Marketing, Erişim:15.06.2019

Yılmaz, A. ve Aykaç, A.S. (2018). Marka İmajının Marka Evangelizmine Etkisinde Marka Güveninin ve Marka Sadakatinin Aracı Rolü, Uluslararası Hakemli Ekonomi Yönetimi Araştırmaları Dergisi, 16: 53-75.

Yüksekbilgili, Z. (2017). Spor Takımı Evangelizmi (Efangelizm) Ölçeğinin Türkçeye Uyarlanması: Güvenirlik Ve Geçerlilik Çalışması, Yönetim Ve Ekonomi, 24(3): 959-969. 